\title{
MARKETING ALBERTA NATURAL GAS IN THE UNITED STATES AFTER THE FREE TRADE AGREEMENT: NEGOTIATING THE U.S. REGULATORY MAZE
}

\author{
DOUGLAS F. JOHN*
}

\begin{abstract}
Although the border between Canada and the United States for natural gas has been open for some time now, the free-market development of natural gas industries is changing from short-term deal-making to long-term industry placement. Here the Canada-United States Free Trade Agreement will take on a critical role in permitting decisions on elements of trade to be made more confidently. This article focuses on key U.S. federal regulatory principles and programs and how Congress's intention in the Natural Gas Act has been carried through so that the federal government will no longer occupy the field of gas regulation, but ensure that where the use of that commodity involves the interests of two or more states, the overall national public interest would be protected. Therefore, producing states would regulate the physical production of gas before it enters the stream of interstate commerce as well as control matters entirely intrastate in nature. The future of contract demand conversions and gas inventory charges will allow customers to purchase gas from a variety of competitive suppliers without suffering a loss of service reliability. In effect gas inventory charges represent the Federal Energy Regulatory Commission's attempt to prevent pipelines from finding themselves with massive take-or-pay liabilities. Through Order No. 436, the Commission has attempted to streamline the regulatory approval process for pipeline construction projects and in turn to foster market competition. The author argues that rate reform is making its way towards what he feels is its natural conclusion where contract, rather than regulation, will be the principal determinant of right and obligation between industry participants at the interstate level. The Federal Energy Regulatory Commission would become more of a referee than director for questions of anti-competitive behaviour in the use of interstate facilities.
\end{abstract}

Ask a natural gas industry participant whether the Canada/U.S. Free Trade Agreement has any bearing on his day-to-day business, and, in all likelihood, you will be told that it does not. After all, the international border between our two countries has been "open" for some time now, so open that a new, short-term import/ export deal using the existing pipeline infrastructure can be brought on line almost overnight. Such is the present nature of our industry, where sales are, for the most part, unregulated, transportation services can be pre-approved and self-implemented and creative use of "agency" relationships permits middlemen to assume the administrative responsibilities of all parties to a transaction.

In many ways, we are still in an experimental stage of free-market development of the American and Canadian natural gas industries. The focus of the experiment is changing, however, from short-term deal-making to long-term industry placement. The client is typically asking himself (and, increasingly, his legal advisor) questions such as: Should I invest in reserves? in pipeline assets? in storage? Should I enter into long-term sales/purchase agreements, or keep my options open? How should I and my counterparts allocate financial risk in a long term transaction? Should I form new corporate entities and if so, what kind?

Analysis of these and other inquiries should reveal that the Free Trade Agreement, contrary to being inconsequential, promises to play a critical role in U.S. and Canadian corporate decision-making, for the simple reason that it permits these difficult decisions to be made more confidently where trade between the two countries is concerned.

* Douglas F. John is a Partner in the Washington D.C. law firm of John, Hengerer \& Esposito. The contributions to this paper of his colleagues at the firm. Ned Hengerer, Peter Esposito and Charles Schultz, are gratefully acknowledged. 
This paper will explore key U.S. federal regulatory principles and programs which should be of particular interest to Canadian companies who are, or plan to be, actively involved in the natural gas business in the U.S. over the long term. The scope of the paper is not all-encompassing; rather, it is issue-specific. Following a brief introduction, it will be divided into three sections. The first section is in the nature of a pot-pourri of topics and issues relating to the importation and marketing of Canadian gas. The second section deals with issues relating to "openaccess" pipeline transportation service. The third section concentrates on facility construction, particularly as it relates to the "Optional Expedited Certificate" procedure and chronicles the history and status of several major pipeline expansion projects of relevance to Canadian producers. Sections II and III are oriented around the Federal Energy Regulatory Commission (FERC) exclusively. Section I draws attention to other federal governmental agencies as well.

\section{INTRODUCTION: THE STATUTORY FRAMEWORK}

Federal regulation of the natural gas industry derives in general from two statutes, the Natural Gas Act of 1938 (NGA), ${ }^{1}$ and the Natural Gas Policy Act of 1978 (NGPA). ${ }^{2}$ The Natural Gas Act is short in verbiage and is essentially an enabling statute. Principles of regulation under that Act are therefore largely the product of agency rule-making and adjudication. Congress enacted the NGA pursuant to its constitutional authority to regulate commerce between the states. Congress' intent in the NGA was not to occupy the field of gas regulation; rather, it was to assure that, where the use of that commodity involved the interests of two or more states, the overall national public interest would be protected. Thus, Congress left to producing states the regulation of activities involving the physical production of gas before it enters the stream of interstate commerce, as well as matters wholly intrastate in nature. Congress also left to consuming states the regulation of matters involving the distribution of gas after it has left the stream of interstate commerce.

For purposes of this paper, the following NGA sections will be focal: section 3 (dealing with gas importation and exportation); section 7 (dealing with construction of jurisdictional facilities and the authorization of jurisdictional services), and sections 4 and 5 (dealing with the rates and conditions under which jurisdictional service may be rendered from time to time).

The NGPA supplemented and in some respects amended the $N G A$. In contrast to the enabling nature of the $N G A$, the $N G P A$ generally gives specific instruction as to how the statutory intent is to be carried out. Of the forty-odd sections of the $N G P A$, the only one treated in this paper is section 311 . In that section, the Congress established a framework whereby interstate and intrastate pipelines could work in tandem to make more efficient use of the national delivery grid. Interstate pipelines were to be allowed to transport gas "on behalf of" intrastate pipelines and local distribution companies without first having to obtain an $N G A$ certificate. Intrastate pipelines were to be allowed to transport gas "on behalf of" interstate 
pipelines and local distribution companies served by interstate pipelines without becoming subject to pervasive FERC regulation under the $N G A .^{3}$

\section{REGULATORY CONSIDERATIONS REGARDING THE IMPORTATION AND MARKETING OF CANADIAN GAS IN THE UNITED STATES}

This section of the paper discusses regulatory requirements affecting the "merchandizing," as opposed to the transportation, of Canadian gas in the U.S. Certain of the points covered below are particularly relevant where the entity in question is interested in determining the extent to which Canadian supplies can be integrated into a supply pool from which that entity will draw to meet its market obligations. Relevant U.S. regulatory requirements and issues will be examined on an agency by agency basis.

\section{A. SECRETARY OF ENERGY}

Section 3 of the Natural Gas Act deals with imports and exports of gas to and from the U.S. It provides that any import or export shall be approved unless it is demonstrated to be inconsistent with U.S. public interest. There is, therefore, a presumption in favor of authorizing such imports or exports; the burden is technically on a protestant to show why the proposed import/export should not go forward. Relevant considerations include price, market need and national energy security.

Under the provisions of the Department of Energy Organization Act of 1977, the Secretary of Energy has authority to allocate NGA section 3 responsibility between units of the Department of Energy (DOE) and the FERC. ${ }^{6}$ Pursuant to that authority, the Secretary of Energy has issued a series of delegation orders, ${ }^{7}$ the effect of which is to limit the FERC's section 3 authority to those situations where a particular import or export will involve the construction of new pipeline facilities in the U.S. Where no such construction will occur, section 3 responsibility resides with the DOE Assistant Secretary of Fossil Energy, upon delegation from the Secretary. ${ }^{8}$ Where such construction is involved, the Fossil Energy Office retains jurisdiction over whether or not to allow the import, but the FERC assumes jurisdiction over the siting of the facilities and, in that vein, to determine whether the proposed facilities are environmentally acceptable.

In 1984, as refined thereafter, the Administrator of DOE's Economic Regulatory Administration (which, until earlier this year, had been assigned DOE respon-

3. 15 U.S.C. \$3371. Actually, section 311 (a) must be read together with section 601,15 U.S.C. $\$ 3431$, wherein is articulated the relationship of the NGPA to the NGA.

4. 15 U.S.C. $\$ 717($ b).

5. 42 U.S.C. $\$ \S 7101$, et seq.

6. Technically, the FERC is under the auspices of the Department of Energy. However, that organizational arrangement in no way confers upon the Secretary of Energy review or veto power over FERC actions. The FERC is an independent regulatory agency, whose members are appointed for fixed terms by the President, subject to confirmation by the Senate. Final actions of the FERC are subject to judicial review in the U.S. Courts of Appeal.

7. The most recent of these is Delegation Order No. 0204-112 (issued February 15, 1984) 49 Fed. Reg. 6690 (February 22, 1984).

8. Delegation Order No. 0204-127 (issued February 7, 1989) 54 Fed. Reg. 11436 (March 20, 1989). 
sibilities under $N G A$ section $3^{\circ}$ ) proclaimed a new policy governing gas imports. Whereas before, each import had to satisfy rigid standards as to import price and contract terms, the new policy manifested a reliance on the market to insure that the border price and contract terms were in the public interest. ${ }^{10}$ Putting that philosophy into practice, ERA/DOE has, for the past three years, issued a series of "blanket" import and export orders to some 100 entities, under which the recipient is authorized, for a period of two years from the date of first delivery, to import gas from and/or export gas to Canada without advance approval from DOE. "Present policy requires the establishment of an annual limit on how much gas can be imported or exported by the recipient, but this cap is pretty much at the discretion of the importer to select in his application. The holder of such an authorization typically can import for his own use or for resale, or can act as import agent for third persons wishing to import gas. In addition to reporting its first deliveries under an ERA/DOE blanket authorization, each permit holder must file a quarterly report of all activity conducted under his permit, in which it is supposed to show how much gas was brought in, for whom and at what border price. These reports are generally terse and the information set out in them is often so sanitized as to be of little use to "competitors" of the reporting entity or its principals. ${ }^{12}$ To what extent DOE analyzes these reports is unknown, but there has to date been no real effort to require more detail.

For longer imports (greater than two years), the importer/exporter must secure specific advance approval from DOE. This has not been difficult to do. Of primary interest to DOE in such instances are the rate methodology and take requirements. The DOE is concerned that the U.S. customer - especially where it is a local distribution company (LDC) - would avoid being subjected to contract purchase prices which are not responsive to the market. DOE is not willing to permit longterm imports unless the market to be served is clearly identified. ${ }^{13}$ It is possible, however, to obtain a hybrid long/short term import authorization, under which gas covered by a market-specific long-term import authorization can be spot-marketed to third parties during a limited period (up to two years), generally for the purpose of avoiding take-or-pay charges. ${ }^{14}$

For the past several years, ERA/DOE has been under considerable pressure from U.S. independent producers to adopt measures to deter importation of Canadian

9. Delegation Order No. 0204-111 (issued February 15, 1984) 49 Fed. Reg. 6690 (February 22, 1984).

10. "New Policy Guidelines and Delegation Orders from Secretary of Energy to Economic Regulatory Administration and Federal Energy Regulatory Commission Relating to the Regulation of Imported Natural Gas," (issued February 15, 1984) 49 Fed. Reg. 6684 (February 22, 1984).

11. The two year limitation has been retained in recent orders, despite requests that it be lifted. DOE's expressed rationale for this term limitation is that it provides the public with protection from "potential adverse consequences of contractual provisions that are not known and therefore not scrutinized by [DOE] at the time of authorization." Tennessee Gas Pipeline Company, Opinion and Order No. 295, ERA Docket No. 88-43-NG (January 18, 1989) at slip opinion p.9.

12. This is probably due in part to the fact that DOE will not accord confidential treatment to the information contained in these reports. See, e.g., Pan National Gas Sales, Inc., Opinion and Order No. 289-A, Docket No. 87-34-LNG (February 23, 1989) at slip opinion pp. 3-4.

13. See Midland Cogeneration Venture Limited Partnership, Opinion and Order No. 305, Docket No. 88-39-NG (March 31, 1989) at slip opinion pp. 9-10.

14. See Tennessee Gas Pipeline Line Company, Opinion and Order No. 295, Docket No. 88-43-NG (January 18, 1989). 
gas. This group has argued, without success that, as a matter of policy, ERA/DOE should refuse to authorize new gas imports where the importing pipeline is not an open-access participant. The U.S. producer group has also argued that the marketbased import policies discussed above were adopted through improper procedures (e.g., without formal consultation with the FERC), such that they are a legal nullity. These arguments have failed at the ERA and, upon review, at the D.C. and Fifth Circuits. ${ }^{\text {is }}$

Certain members of Congress from gas-producing states have also been prevailed upon from time to time to introduce various bills under which ERA/DOE import jurisdiction would in effect be transferred to the FERC. It is apparently perceived by these proponents that the FERC would not be burdened by free-market politics, in particular the consequences of the Canada/U.S. Free Trade Agreement. These bills would also require the FERC to treat all sales of Canadian gas as Natural Gas Act (NGA) sales (an issue discussed in the following section). None of these bills have made much progress.

\section{B. FEDERAL ENERGY REGULATORY COMMISSION}

Beyond the limited section 3 jurisdiction which resides with the FERC, the FERC's authority over the sale of Canadian gas derives from sections 7 and 4-5 of the NGA. ${ }^{16}$ Section 7, inter alia, requires any seller of gas in interstate commerce for resale first to obtain a certificate of public convenience and necessity for that purpose; the rates and charges for such service are then subject to the FERC's jurisdiction under sections 4 and 5 . Sections 4 and 5 require rates to be just, reasonable and non-discriminatory.

There is no question that where an interstate pipeline buys Canadian gas at the border and then resells it to LDC's or other wholesalers as part of its regular system supply, such resale is "jurisdictional". The rates and service conditions for the resale are accordingly subject to the FERC's section 4 and 5 jurisdiction. The

15. Panhandle Producers and Royalty Owners Association v. ERA, 847 F.2d 1168 (5th Cir. 1988); Panhandle Producers and Royalty Owners Association v. ERA, 822 F.2d 1105 (D.C. Cir. 1987).

16. The FERC also has responsibility for issuance of Presidential Permits under old Executive Order Nos. 10485 (September 3, 1953) and 12038 (February 3, 1978). Such a permit must be obtained by any pipeline whose facilities will be used for new service. Presidential Permits are issued after consultation with the Departments of Defense and State. Among other things, they confer upon the U.S. govemment the right to take possession of and utilize covered facilities where national security so warrants. Such permits have already been obtained by the existing pipelines upon whom an importing entity would locigally be relying for transportation of gas on the U.S. side of the border. 
FERC's so-called "as-billed" policy for Canadian gas" is a form of rate treatment affecting interstate pipelines' sales of Canadian supplies. ${ }^{18}$

Where the sale in interstate commerce for resale of Canadian gas is by someone other than a pipeline or LDC, however, there is an open question as to whether the FERC's $N G A$ powers are triggered. ${ }^{19}$ There exists a line of reasoning which has been relied upon by a number of wholesalers of Canadian gas in the U.S. to support the position that the interstate sale for resale of Canadian production by a marketer is not a sale which requires section 7 certification. The question there is whether section 601 of the Natural Gas Policy Act of 1978 has exempted such sale from $N G A$ coverage.

Section 601(a)(1) of the NGPA removes FERC's rate and certificate jurisdiction over "first sales" of gas "which was not committed or dedicated to interstate commerce" as of November 8, 1978. As explained below, this suggests that a present day sale in the United States of Canadian gas for resale, other than by a pipeline or state-regulated gas utility, which was not covered by an NGA section 7(c) certificate on November 8, 1978, would be excluded from FERC's $N G A$ jurisdiction.

Section 601(a)(1) of the Natural Gas Policy Act provides:

(a) Jurisdiction of the Commission Under the Natural Gas Act. -

(1) Sales. -

(A) Natural Gas Not Committed or Dedicated. - For purposes of Section 1(b) of the Natural Gas Act, effective on the first day of the first month beginning after the date of enactment of this Act, the provisions of the Natural Gas Act and the jurisdiction of the Commission under such Act shall not apply to natural gas which was committed or dedicated to interstate commerce as of the day before the date of enactment of this Act solely by reason of any first sale of such natural gas.

17. The "as-billed" policy was first announced in FERC Opinion No. 256, Natural Gas Pipeline Company of America, 37 FERC 61, 215 (1986). Under this policy, the FERC permits an importing pipeline to include in its demand charge on downstream sales only those costs which would have been billed to it as transportation demand charges had it been buying gas from an entity employing the "modified fixed/variable" form of rate design. Costs which the importing pipeline cannot reflect as demand costs must instead appear as commodity costs, for recovery of which the importing pipeline stands at risk. The FERC does not consider itself bound to classify "demand" payments to the Canadian supplier as "demand" costs for the purpose of cost recovery by the pipeline, notwithstanding the fact that DOE may have specifically approved the form of the import contract.

18. Actually, there is a dispute over the extent of this power. Certain importing pipelines have contended that the ERA's authority to approve import pricing terms under section 3 pre-empts the FERC's rate-setting authority under sections 4 and 5. The theory is that, where the FERC's asbilled policy effectively frustrates the demand/commodity price structure of an import arrangement which ERA/DOE has found to be consistent with the public interest, the FERC's policy must give way. This issue has never been fully resolved.

19. The fact that some resellers, such as Boundary Gas, Northwest Alaskan, and Border Gas, have sought and obtained NGA certification for non-pipeline sales in interstate commerce for resale of gas imported from Canada is not dispositive of this legal issue. Neither was the question presented in the Boundary Gas proceedings (in fact, the original draft of the Boundary Phase II order contained some comment on this issue, but that language was stricken from the order before it was issued), nor do the Commission's onders in those proceedings address the question. In the past, there have been many times when a certificate was sought and obtained for an activity later adjudged to be non-jurisdictional (e.g., the construction and operation of gathering facilities). When an application is filed for a certificate, it is unusual for the Commission, on its own motion, to refuse to issue it on grounds of nonjurisdictionality. 
By definition, most, if not all, Canadian gas would not be considered as having been "committed or dedicated to interstate commerce" on November 8, 1978. Section 2(18) of the Natural Gas Policy Act provides that:

The term "committed or dedicated to interstate commerce", when used with respect to natural gas, means -

(i) natural gas which is sold from the Outer Continental Shelf; and

(ii) natural gas which, if sold, would be required to be sold in interstate commerce (within the meaning of the Natural Gas Act) under the terms of any contract, any certificate under the Natural Gas Act, or any provision of such Act.

Nothing in this language or in the NGPA's legislative history limits the exemptive provisions of section 601(a)(1) to domestic production. The gas here in question was neither produced from the Outer Continental Shelf, nor was it required to be sold in interstate commerce by virtue of the provisions of the Natural Gas Act.

Having determined that the subject gas was not committed or dedicated to interstate commerce on November 8, 1978, the next question is whether the sale of it qualifies as a "first sale" under the NGPA. According to section 2(21) of the $N G P A$, a "first sale" is in general any sale of gas, other than sales of gas by an interstate pipeline, intrastate pipeline, LDC, or any affiliate thereof, where the gas sold is not produced by such pipeline, LDC, or affiliate. There is no express requirement that a "first sale" be only of gas which is domestically produced. Canadian sourced production would thus appear to qualify.

With exemption from $N G A$ certificate jurisdiction under section 7 would come exemption from $N G A$ rate jurisdiction under sections 4 and 5 . However, inquiry must be made as to what, if any, "maximum lawful price" under the Natural Gas Policy Act is applicable to first sales of Canadian production within the U.S. ${ }^{20}$ This question is answered simply enough by reference to section 101(b)(4)(A) of the NGPA. Therein it is provided that the maximum lawful prices set forth in Title I apply only to the sale of gas produced in the United States. Canadian gas would therefore appear to be excluded, leading one to conclude that the only form of price/rate control applicable to Canadian gas sales is that embedded in DOE's $N G A$ section 3 examination of the underlying import.

The foregoing discussion is offered here only for the academic interest of the legal advisor and should not be relied upon as demonstrating anything more than that there is a defensible basis for determining that the sale of Canadian production within the U.S. by other than pipelines need not involve FERC regulation. This legal question has been presented to the FERC in a number of contexts, but has yet to receive an answer. In response to a "blanket certificate" application by Pan Trading, a Panhandle Eastern Pipeline Company marketing affiliate, an intervenor charged that Pan Trading should not be permitted to include Canadian gas within the coverage of its authorization. The FERC, in a December 31, 1987 order issuing the blanket sales certificate, responded that it did not read Pan Trading's application as requesting such authorization and that accordingly there was no issue to be resolved, thereby side-stepping the question. There are one or more marketer blanket applications pending in which the issue has clearly been raised, ${ }^{21}$ but those applications appear to be going nowhere until the FERC develops a legal position and/or policy on this subject.

20. Sections 102-109 of Title I of the NGPA define first sale categories and respectively-applicable maximum lawful prices.

21. E.g., Salmon Resources, Docket No. CI87-254-000. 
In another instance, the FERC Staff had become aware of a series of transactions involving sales of Canadian gas by a marketing affiliate of a U.S. pipeline to several LDCs and made inquiries as to how the sale from the marketing affiliate to these LDCs was to be accomplished, inasmuch as the marketing affiliate had not requested certificate authorization for them. Staff was advised that this arrangement had been structured to have the marketing affiliate buy the gas in question on the Canadian side of the border, resell it to the LDCs there and have the LDCs themselves own the gas as it is imported into the U.S. The marketing affiliate would eventually act as import agent for the LDCs. The Canadian supplier in turn arranged to act as export agent for the deal, using its long-term NEB license for that purpose.

The present Commission appears to have no particular desire to impose $N G A$ jurisdiction on these sales of Canadian gas. This Commission is in favor of open competition wherever possible. Despite its "as-billed" policy (or perhaps because of it) the members of this Commission all appear to favour continuous and enhanced U.S./Canadian gas trade. If the legal issue can be resolved against the need for certification, it likely will be. If it cannot be so resolved, then the FERC will probably, as a matter of policy, include Canadian gas within the scope of the blanket certificates they are issuing to marketing companies generally. ${ }^{22}$ While there is of course the possibility that the FERC would take remedial action against those entities who have engaged in unauthorized sales for resale of Canadian gas, there is no requirement that the FERC do so. ${ }^{23}$

There is no way of knowing when the FERC will act to resolve this uncertainty. At least for the time being, a conservative course of action would be to arrange to have the marketing entity act as sales agent, but not as title taker, where the purchaser is an LDC, pipeline, or marketer. Where the buyer is an end user, the marketing entity may take title and resell without fear of $N G A$ consequences, because that sale will not be a sale for resale.

Whether or not the sale in interstate commerce for resale of Canadian gas in the U.S. is determined to require $N G A$ certification, the marketing entity should nevertheless be vigilant as to where the sale takes place, in order to avoid uncertainty as to the applicability of state commission jurisdiction to the sale. To understand why this exposure exists, it is important to recognize that under the $N G A$ Congress chose to give FERC interstitial, as opposed to plenary, power. The FERC's statutory jurisdiction gives way to the jurisdiction of the state where the activity in question

22. Whereas sales of domestic U.S. production by marketers under such blanket certificates would be considered NGPA "first sales" and, therefore, exempt from Natural Gas Act section 4 and 5 rate regulation, this would not be true for these marketers' sales of Canadian production. However, I would expect the FERC to adopt a form of benign rate regulation for these sales, using the rationale that the market controls prices sufficiently for these sales to meet the just and reasonable standards of sections 4 and 5 of the Natural Gas Act. This would be consistent with the philosophy reflected in certain FERC orders involving Gas Inventory Charges (discussed in Section II of this paper, infra).

23. There are many instances where broad reliance on a good faith misunderstanding of the NGA or NGPA have been retroactively forgiven (regulation of producer sales following the 1954 Phillips Petroleum v. Wisconsin decision, 347 U.S. 672 (1954); permission to retain past NGPAprescribed price ceiling payments where the required NGA blanket affidavit had not been filed). In this instance, there would appear to be no basis or reason to push for any sort of sanctions or refunds in the event it is determined that certificates were and are required. 
assumes a local character (e.g., retail sales in the market area). Where the marketing entity makes the sale of Canadian gas outside the state of consumption, this issue should not arise. ${ }^{24}$

Where a pipeline is constructed from the U.S./Canadian border directly to an LDC or end user in the adjacent border state, ${ }^{25}$ FERC jurisdiction under sections 4,5 and 7 of the $N G A$ does not arise, for the reason that neither the sale nor the facility use involves interstate commerce. ${ }^{26}$ The FERC would, however, still be required under section 3 of the $N G A$ to approve the facility construction and the ERA would have to approve the import itself. The FERC section 3 review is, for all intents and purposes, the same as would apply where facilities are proposed for construction under section 7 of the NGA; in addition to the particular bordercrossing facilities to be built, the FERC will examine all related aspects of the project, including facilities which may be built within the state and which may not, in and of themselves, be subject to FERC jurisdiction. In addition to these section 3 requirements, the person planning to construct the pipeline would have to obtain appropriate state authorizations as required for intrastate pipelines generally. Where some sort of LDC bypass is contemplated by means of the proposed pipeline, this state oversight may present an insurmountable roadblock.

\section{U.S. CUSTOMS CONSIDERATIONS}

Under the schedule of commodities incorporated into the GATT, there is no duty on the importation of natural gas from Canada. There are, however, certain filing requirements which must not go unattended.

All importers of natural gas from Canada must file a U.S. Customs Form 7501. The completed Form 7501 must be filed monthly by the importer. The actual due date for these filings may vary among the Customs Service District Offices and it is recommended that early contact be made with the District Office having jurisdiction over the entry point(s) in question. A great deal of autonomy is accorded these District Directors in carrying out their responsibilities.

The volumes shown in this Entry Summary should match with those to be reported by the receiving pipeline (e.g., Northwest Pipeline Corporation (Northwest), Pacific Gas Transmission Company (PGT), Northem Border Pipeline Company (Northern Border)) on its Form 7533, Inward Foreign Manifest, which is due to be filed by the same date each month as is the 7501. Thus, in the event an importer does not expect to receive its pipeline invoice(s) in time to use them for its 7501 report(s), the importer should contact the pipeline(s) to get the necessary information.

As noted, there is no Customs Duty on imported natural gas from Canada. There is, however, a User Fee equal to .17\% (i.e., seventeen one-hundredths of one percent) of the value of the imported gas at the border. ${ }^{27}$ As a result, if the border

24. Making the sale in a state other than that in which the gas will be consumed may also enable the seller to avoid certain taxes which would otherwise apply.

25. This is, for example, the circumstance applicable to Empire State Pipeline, a joint venture of Coastal Corporation and Union Enterprises, which is proposed to be built in upstate New York.

26. Foreign commerce is not synonymous with interstate commerce under the NGA.

27. The Customs Service User Fee regulations are codified at 19 C.F.R. \$24.23. 
price (or netback value) was $\$ 1.50$ (U.S.) per MMBtu for January, the fee per MMBtu would be $0.17 \%$ times $\$ 1.50$, or 0.255 cents. The importer of record must remit a check in the appropriate amount along with the monthly Form 7501. There are also certain bonding requirements which apply to gas imports. These can be intimidating at first glance, but are generally reduced to manageable expense through engaging the services of a reputable, licensed customs broker.

Do not neglect these responsibilities. Although there is no duty and the user fee is nominal, the penalties for noncompliance with the Customs Service's reporting requirements can be substantial.

\section{SECURING ACCESS TO TRANSPORTATION CAPACITY IN THE U.S. AND COMPREHENDING THE CONSEQUENCES}

The FERC promulgated its Order No. 436 on October $9,1985^{28}$ which established a "voluntary" program - known colloquially as "open-access" - under which any interstate pipeline could engage in self-implementing third party transportation service, provided it were willing to do so on a non-discriminatory basis. The statutory bases upon which the FERC acted were sections 4, 5 and 7 of the $N G A$, and section 311 of the NGPA.

Pipelines choosing to participate in the open access program were required to abide by the following threshold rules: (1) both firm and interruptible (to the extent the pipeline had any unsubscribed capacity) transportation services (whether by forward haul or displacement) were to be offered; (2) rates were to be seasonallydifferentiated (where appropriate), mileage-based and designed to recover only costs properly associated with the transportation system (i.e., "unbundled"); (3) rate "bands" were to be established, featuring maximum rates based on full cost allocation and minimum rates based on variable out-of-pocket costs, with "discounting" within the band permissible; (4) access to pipeline firm and interruptible capacity was to be established on a "first-in-time" basis; and (5) firm sales customers of the pipelines were to be given a right to reduce their firm sales contract demand with the pipeline down to zero over a period of five years or, alternatively, to convert all or part of that sales demand to firm transportation demand, with such conversion being accorded a day one "first-in-time" priority. The reduction/conversion rights were to attach regardless of the term of the sales service agreement between the pipeline and its distribution company customer.

Perhaps the most controversial aspect of the program was the contract demand reduction/conversion feature. Most assuredly, it was instrumental in causing many pipelines to delay their acceptance of the FERC's invitation to become open-access. Responding to these concerns, the FERC issued a series of generic waivers of the contract reduction/conversion requirements, during which period many interstate pipelines began performing interruptible transportation service on a provisional basis.

Order No. 436 suffered what appeared to be a setback on June 23, 1987, when the U.S. Court of Appeals for the District of Columbia Circuit issued its $A G D \mathrm{v}$.

28. "Regulation of Natural Gas Pipelines After Partial Wellhead Decontrol", FERC Statutes and Regulations, Regulations Preambles 1982-85 Para. 30,665 (1985) (Order No. 436), vacated and remanded, Associated Gas Distributors v. FERC, 824 F.2d 981 (D.C. Cir. 1987), cert. denied U.S., 108 S.Ct. 1468 (1988). 
FERC decision. ${ }^{29}$ In that decision the Court determined that the FERC had, without adequate reason, elected to ignore the take-or-pay exposure of interstate pipelines who, for competitive reasons, really had no choice but to participate in the program. The Court was particularly critical of the contract demand reduction/ conversion feature in this regard.

On balance, however, the $A G D$ v. FERC decision was a clear victory for the FERC. Aside from its perceived shortcomings from the take-or-pay standpoint, Order No. 436 was upheld in all material respects. In essence the FERC was determined to have acted within its powers in establishing a "voluntary" program for which almost everyone had to "volunteer".

The $A G D$ v. FERC Court delayed issuance of its mandate (which gives effect to its decision) long enough to provide the FERC with an opportunity to promulgate an acceptable interim rule, the effect of which was to avoid a complete shutdown of the ongoing open-access program. This interim rule was announced in FERC Order No. 500, issued August 7, 1987. ${ }^{30}$ In Order No. 500, the FERC: (1) eliminated the contract demand reduction option altogether, but provided additional support for, and retained in its regulations, the contract conversion option; and (2) established, or indicated that it would be amenable to the establishment of, three new mechanisms for dealing with the take-or-pay problem. These three were: (1) an "equitable sharing" method for simplifying the rate passthrough by pipelines of certain buy-out or buy-down costs associated with producer-to-pipeline take-or-pay dispute settlements; (2) a requirement that shippers of gas on openaccess pipelines provide the pipeline, on request, with an offer of volumetric "take-or-pay credits", which could be applied against the pipeline's purchase obligation, if any, with the producer of the gas to be shipped; and (3) a charge designed to compensate the pipeline for the costs of securing and maintaining gas supplies to meet its firm sales contract demand obligations. This latter mechanism will occupy a good deal of attention in the discussion to follow.

Order No. 500 became effective September 15, 1987. Its acceptance as an interim rule has been verified by the Court of Appeals. When it becomes final, it will be ripe for judicial review on its merits. That finality is expected to come some time this year, but the FERC seems to be in no hurry. It is not expected that the Order will be materially changed in its final form. It is further expected that the order will withstand judicial review.

There have been two generations of Order Nos. 436/500 implementation. The first generation, which began as soon as Order No. 436 was issued, dealt largely with interruptible transportation, which is all that was available. The second generation really commenced in early 1988 , when, through contract conversions, firm transportation service began to materialize. The balance of this section of the paper will explore key issues from both generations. Particular subjects will include: (1) transportation rate design; (2) first-in-time capacity allocation and receipt point flexibility; (3) the title requirement and capacity brokering; (4) delivery facility construction and transportation bypass; (5) balancing; (6) the nature and effect of

29. Associated Gas Distributors v. Federal Energy Regulatory Commission, 824 F.2d 981 (D.C. Cir. 1987), cert. denied, U.S., 108 S.Ct. 1468 (1988).

30. "Regulation of Natural Gas Pipelines After Partial Wellhead Decontrol," FERC Statutes and Regulations, Regulations Preambles $\$ 30,761$ (1987) (Order No. 500). 
Gas Inventory Charges; and (7) the concept of "comparable access," ("substantial comparability") as applied to firm transportation service.

\section{A. TRANSPORTATION RATE DESIGN}

As noted, the Commission in Order No. 436 had certain clear preferences as to how transportation rates should be developed on interstate pipeline systems. They were to be unbundled, mileage-based and seasonally differentiated. They were generally to be volumetric; that is, the shipper paid only for service actually received; this in turn meant that the rates for interruptible transportation service would be assigned some share of system fixed costs.

In practice, however, most of these concepts have become largely ethereal. In part to foster early rate settlement arrangements which influenced pipelines' decision whether to join the open-access program, the FERC did not insist on strict compliance with the ratesetting principles of Order No. 436. Today, as a result, the typical pipeline transportation rate structure is not seasonal in nature, is not based on mileage (but rather on production and market zones) and is at best quasi-unbundled.

Virtually all interstate pipeline rates today utilize what is called the Modified Fixed/Variable (MFV) form of rate design. Under MFV, costs are first "functionalized". Those costs assigned to the transportation function are then "classified" as demand or commodity. All fixed costs other than return on equity and associated income taxes are classified as "demand" costs. All remaining costs are classified as "commodity" costs.

Demand costs are then divided between the firm and interruptible service classes based upon estimated annual throughput. Those demand costs assigned to the firm class are then divided in half. One half of these costs become " $D-1$ " costs; the other half are designated 'D-2' costs. D-1 costs are recovered by means of a monthly demand charge which is based on the firm customer's maximum daily quantity entitlement. D-2 costs are recovered by a second monthly charge based on the firm customers' annual quantity entitlement. The purpose behind the D-1/D-2 breakdown is to insulate low load factor customers from what the FERC has historically deemed to be a disproportionate share of system demand charges, as would result if cost responsibility were determined on the basis of peak usage alone.

Commodity costs are recovered through a unit charge on actual throughput. That charge is based on estimated annual deliveries by the pipeline.

With certain slight variations an interruptible transportation rate, which is a onepart volumetric rate, will be equal to the $100 \%$ load factor firm transportation rate; that is, the interruptible shipper pays a rate per MMBtu actually moved equal to the total D-1, D-2 and commodity charges the firm shipper would pay per MMBtu if he called upon the pipeline for service at his daily maximum entitlement every day of the year.

The FERC is today wrestling with several generic uncertainties as to how best to design rates under a mature open-access regime. Among these are:

(1) Functionalization/Unbundling. Especially in view of the fact that some pipelines have allowed their firm sales customers to accelerate radically the regulatorily applicable conversion schedule from firm sales to firm transportation, remaining 
sales customers of the pipeline (often smaller customers, such as municipally owned gas distribution companies) could be facing oppressive demand charges associated with the fixed gathering, processing and third party transportation costs to be absorbed by the system. Should this be viewed as a necessary consequence of unbundling, or should unbundling be tempered so as to spread these costs back over the transportation customers as well?

(2) Seasonal and Mileage-based Rates. Have low-load factor customers been enjoying a free ride under the existing rate structure? Have the zone or "postage stamp" transportation rates in use on many systems resulted in unfair subsidies as among classes of service? Would adoption of seasonal rates obviate the justification for two-part demand rates?

(3) One-Hundred Percent Load Factor Interruptible Rates. Have the interruptible shippers been absorbing a disproportionate share of the cost? Are they entitled to have their rates reduced vis-à-vis firm customers, since their quality of service is lower, but, on a $100 \%$ load factor basis, they are paying equally?

(4) Effect of Gas Inventory Charge. In return for the security that such a charge (discussed in more detail below) provides the pipeline, should the pipeline be asked to assume more risk (e.g., through a lower rate of return on equity) on transportation service?

As this paper was readied for distribution the FERC appeared poised to deal with these and other issues in an omnibus fashion. Between the time this paper was first prepared and delivered in Jasper in mid-June, 1989, the FERC has taken action - in the form of a policy statement - to indicate the corrective course it has in mind. Considering the profound impact on U.S. pipelines which these changes could have on the cost of moving gas, including Albertan gas, on U.S. pipelines, it is imperative that the legal advisor track this process closely. ${ }^{31}$

\section{B. CAPACITY ALLOCATION}

The court in $A G D$ v. FERC chided the Commission for its failure to address the mechanics of first-come first-served capacity allocation in Order No. 436 and pointed out the potential for discriminatory implementation of the rule. The Court, however, deferred to the Commission's decision to implement the allocation rule in its orders on pipelines tariffs: ${ }^{32}$

Nonetheless, as each pipeline elects to become an open-access transporter, it must file tariffs with the Commission to govern the service, which tariffs must include any "operational conditions" the pipeline proposes to apply. These filings afford the Commission an opportunity to develop standards of permissible capacity allocation.

31. In fact, on May 30, 1989, the Commission issued its "Policy Statement Providing Guidance With Respect To The Designing of Rates," 47 FERC 961,295 (1989), Docket No. PL89-2-000, reh'g denied, 48 FERC $\{61,122$ (July 27,1989 ). The stated goal of the policy statement is to enable the participants (to FERC rate proceedings) to develop records on which the ALJ's and the Commission " . . can fashion comprehensive rate design schemes tailored to the particular pipelines which will fulfill the intent of the NGPA that market forces play a more significant role in determining the supply, the demand and the price of Natural gas." The policy statement addresses seasonal rates, division of fixed costs between demand and commodity charges, capacity adjustments, discounted transportation, maximum interruptible rates, and rates for forward haul and backhaul transportation.

32. $A G D$ v. FERC, supra n. 30,824 F.2d 981 at 1006 (D.C. Cir. 1987). 
The resulting jurisprudence on capacity allocation yields several rules of thumb: $:^{33}$ (1) For initial allocation of interruptible capacity on an open-access pipeline, most any method will do (e.g., lottery, open season) so long as it is widely publicized and does not work to the undue advantage of marketing affiliates of the pipeline; (2) Once an interruptible shipper is on line and receiving gas at a particular receipt point, he cannot be "bumped" off line by another interruptible shipper, even if that other shipper enjoys an earlier contract date. Where, however, two shippers wish to begin receiving gas at a new receipt point simultaneously, the first-in-time shipper would be accorded a superior priority. ${ }^{34}$ Further, an interruptible shipper can be bumped by a firm shipper changing receipt points at almost any time; $;^{35}$ (3) Firm shippers are, however, subject to certain receipt point restrictions as well, including that their aggregate receipt point entitlements be no greater than their contractually determined maximum daily quantity entitlement. If a firm shipper wishes to adjust his receipt point quantities among points or add new points, he may do so, provided that he may not bump an existing firm shipper off such point(s) ${ }^{36}$ and (4) Where a shipper is receiving a transportation discount (i.e., paying less than the ceiling rate reflected in the effective pipeline tariff) and a second shipper is willing to pay more, the first shipper can be displaced, provided however, that he must first be given an opportunity to match the higher rate. ${ }^{37}$

Recently, the first-in-time policy was upheld when the Commission rejected a proposal by Arkla Energy Resources to establish an open season for new requests for firm transportation services. ${ }^{38}$ Arkla sought the open season because of a new firm transportation contract which it believed would significantly limit the amount of capacity available for other firm transportation on its system. The Commission, in rejecting the tariff provisions, stated that the "proposed open season procedure would pre-empt the first-come first-served queue already established under Arkla's current tariff provisions" and that the proposed tariff revisions "would allow new shippers who request service during the open season to have priority over firm shippers who are currently in line for service, but whose requests for capacity have not been completely filled" ${ }^{39}$ The Commission also noted that if the tariff provisions

33. These "rules of thumb" apply to most pipelines, but are not universally applicable.

34. "Order Granting Clarification and Denying Rehearing," Colorado Interstate Gas Company, 46 FERC 961,109, Docket Nos. CP86-589-008, RP86-104-010 and RP87-30-017 (January 31, 1989).

35. "Order Granting in Part and Denying in Part Rehearing and Clarification", Northwest Pipeline Corporation, 46 FERC 961,412, Docket Nos. CP86-578-020 and RP85-13-028, (March 31, 1989). In this order the FERC required that the pipeline accord the interruptible shipper twenty-four hours notice of the impending "bump".

36. "Order Granting Rehearing", Panhandle Eastern Pipe Line Company, 46 FERC 961,110 at p. 61,434, Docket No. RP88-88-003 (January 31, 1989).

37. See "Order Approving Contested Offer of Setulement Subject to Conditions," Natural Gas Pipeline Company of America, 39 FERC 961,153 , Docket Nos. CP86-582 and RP86-162 (May 8, 1987), and "Order Granting in Part and Denying in Part Requests for Rehearing and Clarification", 41 FERC 461,164, Docket Nos. CP86-582, RP86-162, RP85-150 and RP86-97 (November 10, 1987). See also "Order Granting in Part and Denying in Part Rehearing and Granting Clarification", Northem Natural Gas Company, 41 FERC 961,158 at p. 61, 398-399, Docket No. RP85-206 (November 9, 1987); “'Onder Granting in Part and Denying in Part Rehearing". United Gas Pipe Line Company, 42 FERC 161,247, Docket Nos. RP88-8, (March 1, 1988).

38. "Order Rejecting Tariff Sheets", Arkla Energy Resources, 47 FERC 961,045, Docket Nos. RP89-105-000 and RP89-105-001 (April 12, 1989).

39. Ibid. at 61,131 . 
were made effective they would establish a claim for new shippers who request capacity during the open season to any future capacity that comes available on the system. This would effectively pre-empt those shippers who were already in line prior to the open season.

\section{TITLE REQUIREMENT AND CAPACITY BROKERING}

As a general rule, the FERC requires that a shipper on an open-access pipeline have title to the gas transported, rather than that he act as an agent for others. The reason for this is to deter evasion on the first-in-time principle. ${ }^{40}$

One of the many unresolved dilemmas under open-access is how to allocate transportation capacity where more than one pipeline is involved in sequential transportation or in the case of transportation for an end user, where a pipeline and distributor are involved and the queue positions of the shippers on those systems are not compatible. For example, assume that an end user enjoys a top priority interruptible transportation entitlement on a distributor, but a low priority on the interstate pipeline delivering gas to that distributor. Assume further that the demand for transportation service to that delivery point is greater than the capacity of the point, such that the pipeline cannot accommodate everyone. Because of his low priority on the pipeline, should the shipper be the first to be refused entry? Or, because of his high priority on the downstream distributor, should the shipper be the first to be granted entry? Simply stated, is it the upstream or the downstream system whose queuing profile determines overall priority? There is yet to be established a clear, generallyapplicable answer to this question. ${ }^{41}$

One way of dealing with this problem - in the face of the title requirement described above - is through the use of a reciprocal buy-sell arrangement between two or more shippers having high priority rights on the systems in question. In the example presented, the end user might arrange to "sell" his field supply to a shipper having a high priority on the pipeline, with that shipper then selling the supply back to him at the distributor's city gate, at a negotiated rate at least equal to the amount "paid" for the gas plus the cost of having it transported on the pipeline.

40. "Order Approving Contested Offer of Settlement Subject to Conditions," Texas Eastern Transmission Corporation, 37 FERC 961,260 at pp. 61,683-685, Docket Nos. RP85-177-000, (December 19, 1986).

41. The answer could come through the implementation of a more flexible, market-oriented approach to capacity allocations. For example, Transwestern Pipeline Company was recently granted a waiver that will allow its interruptible transportation customers to make a one-time, irrevocable transfer of their entitlement to transmission service at their present delivery point to a delivery point that is yet to be constructed on the system, without a loss of priority in the queue. The Commission noted that Transwestern has a single delivery point into California which has a maximum daily capacity approximately equal to Southem California Gas Company's firm entitlement, thus leaving little capacity available for Transwestern's interruptible transportation customers. The Commission stated that granting Transwestem's request authorizing the one-time transfer will not undermine the first-come, first-served principle. "Order Granting request for Waiver", Transwestern Pipeline Company, 47 FERC \$61,340, Docket Nos. RP89-151-000 and 001 (June 7, 1989). 
It is conceivable that the Commission may liberalize its title requirement in the future, perhaps in conjunction with the advent of widespread capacity brokering. ${ }^{42}$ Capacity brokering could, however, proceed without this change. ${ }^{43}$

\section{DELIVERY FACILITY CONSTRUCTION AND TRANSPORTATION BYPASS}

In this era of open-access transportation, concerns about transportation "bypass" have become endemic. "Bypass" refers to two types of situations: (1) a direct delivery connection established between an end user and a pipeline in a manner which displaces a distributor who has historically served, or wishes to serve, that end user's requirements (referred to herein as "distributor bypass"'); and (2) a direct delivery connection between a pipeline and a distributor in a manner which displaces or threatens to displace service being provided to that distributor by another pipeline (referred to herein as "pipeline bypass"). While the second form of bypass will generally involve larger facilities and volumes, as well as a more dramatic rearrangement of industry relationships, it is the former form of bypass which has been the source of more political controversy.

Pipeline bypass may be, and has been, accomplished on a self-implementing basis, under an obscure regulation promulgated by the Commission for application under the NGPA section 311 program. That regulation permits an interstate or intrastate pipeline to build facilities without prior $N G A$ certification where the facilities will be used solely to provide NGPA 311 transportation service. ${ }^{44}$ The ability of the pipeline to recover the costs of those facilities will depend on the outcome of a prudence review in the pipeline's next general rate case. Whereas a pipeline building similar facilities under $N G A$ section 7 certificate authorization would enjoy a power of eminent domain over the necessary rights of way, this power does not attach in the case of NGPA section 311 facility construction. For these reasons (cost recovery exposure, lack of condemnatory power) and perhaps others (such

42. "Capacity brokering" is a concept involving the transfer of capacity rights in pipelines. In one capacity brokering program (authorized but not yet implemented) the FERC has required that all brokering, whether by the pipeline in the first instance or by the holder of that capacity in the case of secondary brokering, must be carried out in a non-discriminatory manner. This apparently means that the holder of the capacity would be inhibited in his ability to select subjectively to whom the capacity will be made available. See "Order Amending Blanket Certificate", United Gas Pipeline Company, 46 FERC 961,060, Docket Nos. CP88-6-001 and RP88-8-007 (January 24, 1989). Recently, the Commission authorized Texas Eastern Transmission Corporation's (Texas Eastem's) Transportation Assignment Program (TAP), under which shippers may assign any part of their firm transportation capacity rights to third parties. The Commission approved TAP proposal subject to the following conditions: 1) that firm shippers brokering their space be precluded from charging rates that exceed what Texas Eastern could charge for the same service; 2) that shippers be allowed to reassign brokered transportation rights and that shippers allocate capacity on a nondiscriminatory, first-come, first-served basis; and 3) that FT-1 shippers be permitted to "repackage" their firm transportation rights and assign those rights on either a firm or interruptible basis. "Order Amending Blanket Certificate", Texas Eastern Transmission Corporation, 48 FERC 961,248 , Docket No. CP88-136-007 (August 22, 1989).

43. Capacity brokering is distinguishable from a transportation "agency" arrangement. Under capacity brokering, the holder of the brokered capacity would presumably have to hold title to the gas to be transported. Under the agency arrangement, the holder of the capacity in question would not have to hold title to the gas.

44. 18 C.F.R. $\$ 284(3)(c)$. 
as a lack of financeability), most major pipeline expansion projects continue to be carried out under $N G A$ section 7 authority rather than under $N G P A$ section $311 .{ }^{45}$

Distributor bypass, although involving smaller investments and facilities, will in virtually all cases require FERC involvement. The pipeline is customarily located in close proximity to the end user's plant; alternatively, the end user will have arranged to lay a connecting pipeline from his plant flange to the pipeline. The FERC does not consider the end user's facilities to be jurisdictional under the NGA, even where they are substantial. ${ }^{46}$ By contrast, the tap, valve, meter and (if any) substation facilities to be constructed by the pipeline at the delivery point will be jurisdictional and must be certificated before they are installed. The FERC has adopted a streamlined, self-implementing procedure whereby this certification will be deemed to have been issued following a "notice" period within which the proposed construction has not attracted objection. ${ }^{47}$

Where there is objection, the matter is transformed into a standard certificate proceeding and no construction may proceed until and unless the FERC so permits by order. In contested cases the FERC has indicated that it will find in favor of the bypass construction unless it determines that the bypass is the product of, or will foster, anti-competitive behavior. ${ }^{48}$

\section{E. BALANCING}

The Commission's willingness to provide shippers with capacity on a pipeline's system and the flexibility to use that capacity has uncovered a plethora of "system management" problems related to overruns and imbalances. Because shippers cannot always assure that they will take from a pipeline exactly the same amount of gas which they have injected into it, there is often an imbalance between receipts and deliveries. When imbalances rise to certain levels they can interfere with pipeline operations. As a result, pipelines have proposed to penalize shippers for maintaining imbalances above certain threshold levels. It is therefore not surprising that one of the most widely debated groups of tariff and contractual provisions have been those related to balancing receipts and deliveries.

45. See the discussion which follows on the "optional expenited certificate" procedure developed by the FERC in Order 436.

46. See, e.g., "Onder Issuing Certificate", Natural Gas Pipeline Company of America, 40 FERC \$61,119, Docket No. CP86-574-000 (July 31, 1987). In this case, International Paper planned to lay two lines to the Natural system, each of which was to be over thirty miles in length, large volume, and high pressure. The FERC held them to be exempt from NGA jurisdiction notwithstanding their physical character.

47. 18 C.F.R. \$157.211.

48. "Opinion and Order Affirming in Part, Reversing in Part and Modifying Initial Decision", Panhandle Eastem Pipe Line Company, 40 FERC 961,220, Docket Nos. CP86-232-000, Opinion No. 275-A (September 10, 1987), reh'g denied; “"Opinion and Order Partially Granting and Denying Rehearing", Panhandle Eastern Pipe Line Company, 42 FERC 161,076, Docket No. CP86-233-008, Opinion 275-B (January 27, 1988). The United States Court of Appeals for the District of Columbia subsequently affirmed the Commission by upholding National Steel Corporation's right to bypass Michigan Consolidated Gas Company by a direct interconnection with Panhandle Eastem. See Michigan Consolidated Gas Company v. FERC, D.C. Circuit, Case No. 88-1062 (August 18, 1989). 
Pipelines are not, under open-access, required to provide balancing services for shippers ${ }^{49}$ Shippers opposed to the imposition of balancing penalties and charges $^{50}$ have argued that neither are based on cost. The Commission has responded that: ${ }^{31}$

We see no merit to these arguments. First, the penalties are not intended to compensate El Paso for the costs it incurs when a shipper overdelivers. The penalties are intended to deter conduct that adversely affects the efficient operation of El Paso's system. Nothing in the Natural Gas Act prohibits this, and the Commission has imposed penalties in similar situations before. Hence we can perceive no objection to El Paso's proposal on this score.

Shippers have also proposed that pipelines simply curtail receipts or deliveries in order to rectify imbalances. These suggestions have met with a similar response: ${ }^{52}$

[C]urtailing deliveries to shippers that do not balance is not an adequate substitute for the penalties.

Curtailing deliveries is drastic. It should be limited, as El Paso has done, to situations where action is needed to protect the integrity of the system.

The Commission has thus determined that imbalance penalties and charges are simply "reasonable operating conditions". 53

There are two types of situations often lumped under the rubric of "imbalances". One is when the shipper exceeds its contractual entitlement to service (overruns); the other is when receipts and deliveries do not match (imbalances). The Commission considers both these situations as ones to be avoided and, thus, has allowed penalties to be imposed on conduct resulting in either. In fact, two overlapping penalties - one for each type of conduct - may be imposed. ${ }^{54}$

Yet another situation that may be the subject of deterrent penalties and charges is when a shipper nominates more gas than it has actually transported. The Commission has allowed the imposition of penalties in this situation also, reasoning that, if one shipper nominates a certain volume, it may preclude another shipper

49. "Order Approving Contested Offer of Settlement as Modified and Clarified", Transwestern Pipeline Company, 38 FERC 961,061 at p. 61,172, Docket No. RP85-175-000 (January 28, 1987). In the Columbia Settlement Order the Commission stated that although the primary responsibility for monitoring transportation rests with the shipper, the pipeline is responsible for monitoring events within its control. "Order Approving Contested Offer of Settlement Subject to Conditions and Denying Rehearing", Columbia Gulf Transmission Company, 39 FERC 961,335, Docket Nos. RP86-14-000 and RP86-108-000 through -016 (June 18, 1987).

50. A new vernacular has arisen with respect to balancing. Balancing "penalties" and "charges" are distinguished only by their levels: "penalties" are normally imposed after shippers break thresholds that are higher than for "charges", and the amount of a "penalty" is normally greater than the "charge".

51. "Order Approving Contested Offer of Settlement Subject to Conditions", El Paso Natural Gas Company, 35 FERC 161,440 at p. 62,067 (June 27, 1986) (hereinafter " El Paso 436 Settlement order").

52. Ibid.

53. See also "Order Approving Contested Offer of Settlement Subject to Conditions", Texas Eastem Transmission Corporation, 37 FERC 961,260 at pp. 61,686-687, Docket Nos. RP85-177-000, (December 19, 1986); “'Order Approving Contested Offer of Settlement Subject to Conditions and Issuing Blanket Certificate", United Gas Pipe Line Company, 39 FERC 961,152 at p. 61,574, Docket Nos. CP86-526-000 and RP86-158-000 (May 8, 1987), where the Commission noted that " . . . United is entitled to protect the integrity of its system."

54. El Paso 436 Settlement order, supra n. 52, 35 FERC at p. 62,068. 
from sending its gas and the pipeline may ultimately be denied the revenues applicable to the gas that is not transported as a result of the overnomination..$^{35}$ In fact, attaching great importance to deterring overnominations and in stark contrast to overrun and imbalance penalties, the Commission has allowed overnomination penalties to be imposed without prior notice to the shipper. ${ }^{56}$ Imbalance penalties, by contrast, may be imposed only after the shipper has been notified of the imbalance and given a reasonable opportunity to cure it. Two days is considered a reasonable period of time for correction of daily imbalances; forty-five days is standard for correction of monthly imbalances. ${ }^{57}$

The amount of the applicable penalties will vary among pipelines. Because the purpose of the penalties is to deter behavior, the FERC does not require there to be any particular cost basis for the penalty. In fact, the FERC recently rejected an attempt by a pipeline to use its jurisdictional overrun sales rate as a penalty charge applicable to takes by a transportation customer in excess of deliveries to the pipeline by the customer. The FERC viewed this as an attempt by the pipeline to sell unneeded system supply to customers who had no desire to buy it and condemned the practice as inconsistent with the discipline building purpose of imbalance penalties. $^{58}$

\section{F. GAS INVENTORY CHARGES}

As observed earlier in this paper, despite the fact that the pro-competitive, openaccess promise of Order No. 436 had been in existence for more than two years, at the end of 1987, the vast majority of firm pipeline capacity was dedicated to the fulfillment of the firm system supply obligations of pipelines to other pipelines and LDCs. As a result, most non-pipeline sales being made to LDC customers were short-term and interruptible. ${ }^{\$ 9}$ Since the beginning of 1988 , however, contract

55. Bid. at p. 62,069-70. The Commission rejected a proposal that the overnomination penalty not be applied when all requests for service are satisfied, affirming that the reason for the penalty is not to remedy harm, but to deter conduct.

56. Ibid. "These problems cannot be remedied by the shipper subsequently delivering the underdelivered volumes."

57. "Order Accepting Tariff Sheets Subject to Refund and Conditions and Consolidating Proceedings", Panhandle Eastem Pipeline Company, Docket Nos. RP88-262-002, CP89-917-000 (March 31, 1989); See also "Order Approving Contested Offer of Settlement Subject to Conditions", Texas Eastem Transmission Corporation, 37 FERC Para. 61,260 at p. 61,689, Docket Nos. RP85-177-000, RP85-176-000, RP83-35-000, RP81-109-000, RP74-41-000, TC86-3-000 and RP85-177-018 (December 19, 1986).

58. "Onder Modifying and Approving Base Stipulation and Agreement and Denying Motion to Sever", Unired Gas Pipe Line Company, 46 FERC 961,314 at p. 61,949, Docket Nos. RP85-209 (March 17, 1989).

59. To date, most non-pipeline sales to LDCs have been from the spot market and have been transported under interruptible rate schedules, thus making them "opportunity" types of transactions: when the opportunity arises to transport cheaper spot suppliers, the seller and purchaser can do business; when it does not, the LDC purchases from its firm supplier, the pipeline. 
demand (CD) conversions have become available under the Order No. 500 schedule ${ }^{60}$ and more accelerated conversions are anticipated under Gas Inventory Charges (GICs) that are either being implemented, about to be implemented or proposed. Thus, a major promise of Order No. 436 - that customers can purchase gas from a variety of competitive suppliers without suffering a loss of service reliability - is much closer to being fulfilled.

To date, a number of factors have combined to limit the extent of CD conversions and to lessen their impact on gas markets. First, for customers that needed to utilize their full sales entitlements to meet their base-load requirements, a conversion to firm transportation service was not necessarily a reasonable substitute for firm purchases by the pipeline. This is because the pipelines' firm sales service was backed by considerable flexibility which allowed the pipeline to switch supply receipt points with little or no notice, to rely on storage and to use upstream facilities. This flexibility did not automatically come with firm transportation service. ${ }^{61}$

Second, customers that convert to firm transportation consent to automatic ("pregranted") abandonment of the pipeline's transportation service obligation at the end of the term of the firm transportation contract and also to the abandonment of the converted portion of the pipelines' sales obligation. Thus, in a short number of years, the LDC could conceivably be without sales or transportation service.

In recent months, however, the Commission has recognized these problems and acted to deal with them. The chosen vehicle has, for the most part, been GIC proceedings ${ }^{62}$ These proceedings now portend changes in the terms and conditions under which firm transportation services are provided and offer the promise of competition for firm sales to LDCs.

GICs (also known as Inventory Holding Charges, or IHCs, among other things) represent the Commission's attempt to prevent pipelines from finding themselves

60. 18 C.F.R. \$284.10. Under that schedule, pipelines' firm sales customers could convert their firm sales entitlements to firm transportation at the rate of $15 \%$ per year for the first two years, $20 \%$ in the third year and $25 \%$ in each of the fourth and fifth years after the pipeline began open-access transportation service. The availability of firm transportation arising from the implementation of $\mathrm{CD}$ conversions under this schedule had been delayed for a number of years due to waivers of $\$ 284.10$ of the regulations that had been granted by the Commission through the end of 1987 . Once these waivers expired, the $\$ 284.10$ schedule of conversions was activated.

61. For example, one pipeline, Natural Gas Pipeline Company of America (NGPL), limited firm transportation contracts to include 5 receipt points, hardly enough to depend on for firm supply needs. When that pipeline settled on an interim GIC with its customers, hardly any conversions were elected. In contrast, Northwest Pipeline Corporation (Northwest), with only a couple of major receipt points, gave its customers an unfettered conversion option, and roughly 85 percent of its sales CDs were converted.

62. Just as it did as a means of encouraging pipelines to accept open access blanket certificates, the Commission appears to be holding out a carrot - GICs - to pipelines that are willing to accept pro-competitive changes in the way they do business. For example, although the regulations state that, at the termination of open-access firm transportation service agreements, pipelines can abandon the service, the Commission has recently noted the need for service to continue indefinitely as a prerequisite for granting a GIC certificate. See, "Order Establishing Procedures and Consolidating Proceedings" , El Paso Natural Gas Company, 47 FERC 961,108, Docket Nos. CP88-434 and RP88-185 (April 27, 1989) (hereinafter "El Paso GIC order"). 
with massive take-or-pay liabilities. Many attributed those take-or-pay liabilities to Order No. $380,{ }^{63}$ which outlawed the collection of minimum commodity bills. ${ }^{64}$

The Commission, in part to distinguish GICs from the minimum bills that it had outlawed just three years before, has established a set of criteria for the implementation of GICs: $: 5$

(1) the charge should be the only means by which the pipeline recovers future take-or-pay costs;

(2) the pipeline must allow its customers to nominate levels of service freely within their firm sales entitlements, or otherwise employ a mechanism for the renegotiation of levels of service at regular intervals; (3) the pipeline must announce in advance the price or pricing formula that will be in effect during the period for which nominations are made; and (4) the customer must consent to the abandonment of service for any difference between the nominated level of service and its previous firm sales entitlement.

In essence, the FERC has differentiated minimum bills from GICs by pointing out that, under a GIC, the pipeline's customers are allowed to nominate "freely" their minimum purchase obligation when the price of gas changes, an option that was not generally available under the pre-Order No. 380 regime.

The FERC has gone through a number of GIC proceedings since the issuance of Order No. 500 in mid-1987. Due in part to a number of issues left unanswered in Order No. 500, it took almost two years before the first GIC took effect, despite the Commission's attempts to expedite their consideration. The following discussion focuses on GICs that either are taking effect or the litigation of which is about to begin under recently issued FERC guidelines.

The pricing aspect of the GIC envisioned in Order No. 500 has undergone considerable evolution. Early on, the FERC expressed the opinion that GICs must be fixed as to price for a specific period of time. ${ }^{66}$ In contrast, more recent orders

63. FERC Stats. and Regs. $\{30,571$ (1984).

64. As the theory went, if the pipelines' customers could not be forced to purchase gas from the pipelines in order to meet their minimum commodity bill obligations, then they could buy gas from anywhere (and did), thereby leaving the pipelines with massive take-or-pay obligations and no sales with which to extinguish those obligations.

65. Order No. 500, supra, at p. 30,792; "Order Accepting for Filing and Suspending Tariff Sheets Subject to Refund and Conditions, and Establishing Hearing", Natural Gas Pipeline Company of America, 41 FERC 961,119, Docket Nos. RP87-141 and RP87-141-001 at p. 61,287 (October 30, 1987).

66. In "Order Approving Contested Offer of Settlement, Subject to Conditions, and Establishing Hearing Procedures", Northwest Pipeline Corporation, 42 FERC 161,019, Docket No. CP86-578-000 (January 19, 1988), the FERC stressed this point:

Furthermore, the charge is not known to the customer in advance because Northwest proposes to adjust the estimates on which the GIC is based at the end of each year to conform to actual experience. In this respect, the GIC tracks actual costs and is counter to the principles that sales rates should be prospective and that a maximum commodity charge should remain in effect throughout the nomination period, so that customers can take known costs into account when they nominate levels of service.

Ibid. at 61,004. 
have allowed for the use of a price "formula" that bears little resemblance to what was envisioned in Order No. $500 .^{67}$ In perhaps an extreme case, the FERC approved an agreed upon formula that is simply a fixed percentage add on to the pipeline's weighted average cost of gas in conjunction with very limited conversion rights. ${ }^{68}$ In litigated cases, it appears that the FERC will be more stringent in its application of the Order No. 500 pricing standards.

Order No. 500 simply provided that a pipeline may include in its tariff a "charge" for standing ready to provide service. ${ }^{69}$ The FERC did not specify if this charge was to be paid whether or not gas was purchased (a demand based charge) or only if a certain amount of gas was not purchased (a deficiency based charge). This choice has a significant potential impact on the market.

As discussed above, GICs, particularly those that are deficiency based, have been attacked as being nothing more than a substitute for a minimum bill. In addition, deficiency based charges have been characterized as shielding a substantial portion of the pipeline's market from competition. In theory at least, competing suppliers must beat the price being offered by the pipeline by at least the amount of the GIC charge for all volumes subject to the GIC. Of course, if a pipeline's customers can freely nominate the entitlement level upon which a GIC is charged, then they are theoretically free to nominate zero and buy gas from whatever supplier they choose, without those suppliers having to beat the pipeline price by the GIC. In addition, to the extent that the deficiency level at which the GIC charge begins to apply is low enough, then the increment above the threshold is open to competition unaffected by the level of the GIC. ${ }^{70}$

Demand based GIC charges, on the other hand, become what amount to sunk costs. If a pipeline customer has paid the GIC, then it can purchase all its gas from whatever sources it chooses, without having to worry about paying additional charges should purchases from the pipeline fall below a threshold level.

67. Similarly, the Commission at first was adamant that pipelines could not charge "exit fees" when a customer reduced its nomination as a result of a price change. See, e.g., "Order Granting Rehearing in Part and Clarifying Prior Order", Transwestern Pipeline Company, 44 FERC 961,164 at 61,536, Docket Nos. CP88-99-000, CP88-99-001, CP88-100-000, CP88-143-000 (July 29, 1988). More recently, however, the Commission indicated that it would accept an exit fee when it does not apply to initial nominations under the GIC, but instead when "the charge is intended to apply in situations where a customer terminated its supply contract prior to the end of the time period covered by the customer's nominations". El Paso GIC order, supra note 63, slip opinion at p. 30.

68. "Order Denying Rehearing, Denying Requests For Stay, Granting Clarification And Late Interventions", Texas Eastern Transmission Corporation, Docket Nos. RP85-177-057 and CP88-136-057, at slip opinion p. 12, (April 21, 1989) (hereinafter "TETCO GIC Rehearing order"). The FERC here noted (almost as an aside) that "In any event, as discussed above, Texas Eastem proposes to refund amounts collected in excess of costs."

69. Codified in 18 C.F.R. $\$ 2.105$.

70. For example, if the GIC is levied daily based on 40 percent of a customer's daily entitlement, a customer that needs 100 percent of its entitlement can purchase 60 percent from suppliers who can compete "heads up" with the pipeline's price. The other 40 percent will arguably be "protected" from competition by the amount of the GIC. Ironically, this could tum the spot market on its head, from a vibrant off-peak market to a peak "swing" market, if pipeline customers choose to purchase their GIC threshold amount from the pipeline each day of the year. In its $E l$ Paso GIC Order and "Order Establishing Hearing Procedures", Transcontinental Gas Pipe Line Corporation, 46 FERC 961,364 (March 24, 1989) (hereinafter "Transco GIC order") the Commission focuses on the possibility of allowing monthly nominations, which would allow the customer to choose whether the pipeline will assume the role of swing or base-load supplier. 
At this point, a debate is continuing among the members of the FERC over whether demand or deficiency based GICs should be favored.

The free nominations aspect of the Order No. 500 formulation of GIC policy has also been utilized by the FERC to justify the approval of non-cost-based

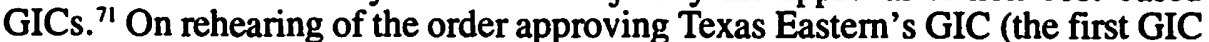
to be implemented) the FERC emphasized that: ${ }^{72}$

Among the features of the settlement which provide benefits to Texas Eastem's customers are the customers' right to reduce their sales $C D$ to zero or to convert up to 100 percent of that $C D$ to transportation as new service contracts are signed, and the right to convert up to 50 percent of their remaining sales CD to transportation over the life of the settlement. Thus the settlement requires Texas Eastern to transport some of its competitors' gas if its customers decide that to be in their best interest. The standby service provided by Texas Eastem also enhances its customers' ability to utilize competing supplies since it enables the customers to take alternative interruptible supplies while maintaining the same quality of service to their customers.

Inherent in being able to nominate freely is the ability to utilize alternative suppliers to achieve the same level of service as has historically been provided by the pipelines. This theory has become inextricably tied with attempts to impose GICs based on market, as opposed to cost-based, pricing. ${ }^{73}$

\section{G. "COMPARABLE ACCESS"}

In the FERC's April 27, 1989, El Paso GIC order, the Commission, obviously frustrated by its inability to formulate GICs that will be accepted by pipelines and customers alike, chose to bypass the normal decision making process and conduct on its own what is in essence a "paper" hearing on a GIC proposed by El Paso

71. This is important because, traditionally, the Commission has been required to use cost-of-service ratemaking concepts in determining just and reasonable rates. For example, during the shortages of the 1970's, every time the Federal Power Commission (FPC) tried to increase wellhead prices by substituting market value for strict cost-of-service rate-making, the courts reacted negatively. United Gas Improvement Co. v. FPC, 290 F.2d 133 (5th Cir. 1961), cert. den., 368 U.S. 823; Bel Oil Corp. v. FPC, 255 F. 2 d 548 (5th Cir. 1958), cert. den., 358 U.S. 804. While the courts gave lip-service to the FPC considering so-called "non-cost factors" in order to encourage exploration and development of gas reserves for the interstate market, the latitude given was extremely limited. Moss v. FPC, 502 F.2d 461 (D.C. Cir. 1974), rev'd. in part on other grounds, 424 U.S. 494.

72. TETCO GIC Rehearing order, supra note 69, slip opinion at pp. 2-3. Notably, the Texas Eastern settlement would allow only limited conversion rights for the 10 years after the first conversion. The FERC found that the difference between the limited conversion rights and free nominations was not significant in the overall context of the case, which included customer support for the settlement and other "substantial benefits".

73. On May 30, 1989, the Commission issued a "Notice of Proposed Policy Statement" for the implementation of interim gas inventory charges, 47 FERC 961,294, Docket No. PL89-1-000. The proposed policy statement detailed several possible methods for developing an interim "gas supply charge" and a "limited term gas inventory charge". The Commission put forth alternative two-part proposals with the major differences between the proposals being whether the PGA is retained and whether the charge will be deficiency-based or not. The "without PGA competitive price method" would be based on demand and would include an interim gas commodity charge based on a competitive market price composite and an interim gas inventory charge based on the composite multiplied by a percentage factor. Altematively, the "with PGA: cost-based method" would be based on deficiency and would include an interim gas commodity charge based on WACOG and an interim gas inventory charge whose rate is based on percentage of WACOG. The deficiency based method is applicable only if a firm sales customer's actual purchases fall below a percentage of either its monthly or annual nominated purchase amounts. 
Natural Gas Company (El Paso).$^{74} \mathrm{El}$ Paso has proposed a deficiency based GIC that will be based primarily on negotiations with its customers. El Paso has alleged, but has not shown to the satisfaction of the Commission, that its markets are "workably competitive", and, thus, that there is no need for the GIC to be based on cost.

As had been the case with respect to earlier proposals by Northwest Pipeline Corporation (Northwest) and Natural Gas Pipeline Company of America (NGPL), the issue has become whether the pipeline's customers can be assured that they have workable options for obtaining service comparable to that offered by the pipeline from other suppliers: ${ }^{75}$

(1) that they will have access to reasonable substitutes for their gas requirements, (2) that they will be able to receive the same quality of service from an alternative supplier that is now provided by Northwest, [and] (3) that offers of substitute service will include assurance of viable transportation to the city gate.

This concern with the availability of alternative supplies has developed from a general concern expressed in early GIC orders, through to a specific set of essential prerequisites and further to an imposition of a market based GIC. In earlier proceedings, these characteristics had been advocated by independent marketers and given the shorthand label of "substantial comparability".

In El Paso, the FERC has apparently adopted both the label and the concept. There, the Commission specifically stated that it: ${ }^{76}$

. . . considers it essential for El Paso to demonstrate that it will provide substantial comparability in service for both sales and transportation customers. The Commission is interested in assuring that El Paso will provide firm transportation to those who convert at rates comparable to the transportation component of the firm sales rate.

Items to be addressed to make this showing will include:

(1) the availability of firm capacity on El Paso's laterals, gathering systems and mainline receipt points and those of interconnecting pipelines;

(2) receipt point flexibility " . . . that is sufficient to allow firm transportation customers to deal with supply interruptions from suppliers without suffering interruptions in their service."

(3) whether there are sufficient "divertible supplies" "77 to satisfy El Paso's customers' demands should they choose not to purchase from El Paso;

(4) the extent to which El Paso's customers will have access to firm storage service and whether, in the alternative, firm transportation could " . . . be equivalent to transportation provided under firm sales without access to storage;"

74. El Paso GIC order, supra n. 63. See also Transco GIC Order, supra n. 71.

75. Northwest Pipeline Company, supra, at p. 61,104; See also "Order Accepting for Filing and Suspending Tariff Sheets Subject to Refund and Conditions, and Establishing Hearing", Natural Gas Pipeline Company of America, 41 FERC 961,119 at pp. 61,288-89, Docket Nos. RP87-141-000 and RP87-141-001 (October 30, 1987).

76. El Paso GIC order, supra n. 63, at slip opinion p. 18.

77. "Divertible supplies" are defined as

. . . that portion of the gas controlled by El Paso's competitors that can be diverted to El Paso's delivery markets within a certain time period. It does not include gas controlled by El Paso or under long-term contract to other buyers, unless the contracts are near expiration. Divertible gas must be available in sufficient quantities to prevent the exercise of market power during peak periods, as well as on an annual basis.

El Paso GIC order supra n. 63, at slip opinion n. 29. 
(5) how El Paso will guarantee that customers converting to firm transportation can contract for transportation for as long as they desire such service; and

(6) how El Paso will provide the same or similar scheduling and nomination procedures for firm sales and transportation services.

The fact that the Commission is asking these questions shows how far along the analysis of workably competitive markets has come. For instance, during the early days of GIC jurisprudence, there appeared to be an assumption that, because the pipeline is offering firm transportation as an option to its customers who choose not to pay the GIC, the customer could "freely nominate" its contract demand under a GIC. Now, however, the Commission appears ready to explore in some detail whether firm transportation tariffs as now formulated allow sufficient flexibility such that the pipelines' customers can in fact make a choice not to rely on the pipeline yet still feel comfortable that they can meet their obligations to their customers. This is further shown by the Commission's questions regarding the availability of storage and transportation on upstream pipelines, both of which have traditionally been used by the pipeline to serve its customers.

In fact, the Commission has taken the concept further than first envisioned by the marketers who suggested it. When originally proposed, the theory dealt primarily with access to transportation and storage with the same flexibility inherent in pipeline sales services. However, the logical extension of the theory - that LDCs can replace pipelines as suppliers without any diminution in reliability of service - brings the Commission to question non-asset use matters, such as the availability of "divertible" supplies.

The major problem in implementing the comparability concept has been how to allocate facilities now used by the pipelines between the pipeline (as a merchant) and its converting customers. After many formulas had been suggested in settlement negotiations (e.g., prorationing of receipt point capacity), a simple idea was offered: "why not make the pipelines sell gas at the upstream end of the system - as opposed to the city gate - and then have the LDCs ship the gas under firm transportation agreements?' In this way, all suppliers will be on an equal footing, with no supplier, i.e., the pipeline, having more flexibility in using the system than another.

Several pipelines are exploring this possibility in settlement negotiations. One, Transco, has already implemented it in a settlement offered to resolve a number of outstanding rate and take-or-pay flowthrough cases. It is now up to the Commission to address this suggestion head on. If it proves a workable suggestion, it may well be the roadmap pipelines need to present to the FERC in order to get rapid approval of GIC proposals. If this turns out to be the case, the competitive landscape will, finally and conceivably quite quickly, be altered from being dominated by spot-market-based sales to longer-term firm sales.

\section{U.S. PIPELINE CAPACITY EXPANSION IN A COMPETITIVE ENVIRONMENT}

As the U.S. natural gas industry has evolved toward a more competitive, less traditional utility-regulated model there has been a proliferation of pipeline expansion proposals, as well as certain structural changes in regulating the certification (approval) process. In that the U.S. remains a major export market and certain 
geographic markets have incremental growth potential and/or insufficient firm transmission capacity, Canadian suppliers should have an ongoing interest in these developments.

The outcome of this certification frenzy remains to be seen. The major facilities presently linking U.S. markets to Canadian gas supplies are the product of either a bygone, less-complex era (PGT, Great Lakes, Midwestern and the Tennessee Spur at Niagara, New York were certified in the 1950's and 60's) or extraordinary U.S./Canadian intervention and cooperation at the highest level of government (PGTI Western Leg Prebuild of ANGTS, Northem Border-Eastem Leg Prebuild of ANGTS).

In contrast, the so-called "consolidated boundary proceeding" to expand firm capacity for new Canadian imports to the Northeast U.S. market lumbered out of control at FERC from 1981 until its death in 1987, with the advent of the "Northeast Open Season", which itself will soon celebrate its second anniversary without any new facilities linked to Canada in the ground. The question must be asked whether current competitive and regulatory conditions will allow for successful certification of one or more major expansions of capacity for Canadian gas. The following factors may influence the answer:

(1) Inter-pipeline competition has reached almost epic proportions, with the substitution of the transportation function for the merchant function as the only realistic direction for pipeline growth. The pernicious regulatory strategies which have resulted have done much to draw out the FERC proceedings involving both California and the Northeast.

(2) U.S. domestic producer groups have also become very belligerent - though so far generally ineffective - in their attempts to use the regulatory process to hinder increased imports of Canadian gas.

(3) Despite FERC's statements about expedition, extended delays in obtaining certification continue to plague bona fide efforts to put new capacity in place, with the result that either the market or the supply, or both, lose interest and pursue other alternatives.

(4) As evidenced by the pending TransCanada 1990 facilities proceeding before the National Energy Board (NEB), securing large-scale export and related upstream facilities approval appears less assured than in the past.

Thus, there is a compounding effect of the resulting regulatory uncertainties on both sides of the border, which could put Canadian gas projects at a disadvantage relative to those supplied solely by domestic sources.

This section of the paper will initially focus on the mechanism devised by the FERC in Order No. 436 as a means of streamlining the regulatory approval process for pipeline construction projects designed to foster market competition. Attention will then be devoted to the history and status of particular expansion projects proposed for the U.S. East and West Coast markets, which markets are recognized as being of vital interest to Albertan producers. Whether the new mechanism has been serving, or promises to serve, its intended purposes in these contexts will be an issue with respect to which judgments may well differ. 


\section{A. THE “OPTIONAL EXPEDITED CERTIFICATE”' PROCEDURE IN GENERAL}

\section{Background}

Traditionally, certification by the FERC of interstate pipeline expansion or new pipeline construction under section 7 of the Natural Gas Act, 15 U.S.C. \$717f, has been a time consuming affair. This is especially true where two or more pipelines propose to serve the same market, or to traverse a common route. Thus, in 1976, when it became clear that multiple applicants were intent on installing delivery systems to carry North Slope Alaskan gas to markets in the lower forty-eight states, the spectre of administrative "gridlock" led to the enactment of special federal legislation to forestall this result. ${ }^{78}$

Legislative relief of the sort embodied in the ANGTA is exceedingly rare and hard to obtain. Therefore, when FERC, in Order No. 436, turned its attention toward capacity construction as part of its grand design to infuse competition into the natural gas industry, it chose to work with the regulatory tools at its disposal. Therewith was conceived the "optional expedited certificate" (OEC) procedure, the thrust of which is to provide an interstate pipeline a means of cutting regulatory delay, provided the pipeline is willing to operate on an open, competitive basis.

In Order No. 436 the FERC portrayed the OEC procedure to be of real competitive advantage, in part to induce pipelines to become "open access" transporters (only "open-access" pipelines can use this procedure). However, at first there were few takers and FERC's dilatory handling of those few OEC applications generated skepticism in the industry. Recent developments have, however, somewhat tempered - though not eliminated - this skepticism.

\section{Summary of OEC Requirements}

The FERC's regulations codifying the optional expedited procedure are found at 18 C.F.R. Part 157, Subpart E. The fundamental theory underlying the OEC procedures is that the sponsor assumes the financial and economic risk of the new project (instead of the standard pipeline approach of having the customers guarantee recovery of all prudently incurred costs). The pipeline also agrees to open competition and to having no cross-subsidies on its system. In return, the FERC can eliminate its normally detailed review to assure that the project is prudent and beneficial to the customers.

Under the OEC procedure, a pipeline applicant's evidentiary burden is considerably lessened vis-à-vis the applicant who proceeds under generally applicable section 7(c) requirements. In terms of exhibits normally required to be filed with FERC supporting a certificate application, OEC applicants are exempted from the following: detailed gas supply data; detailed market data; and tariff, cost of service study, allocation study, rate base and rate of return. ${ }^{79}$

By the same token, the OEC application must contain several additional items: a clear statement that an OEC certificate is sought; an express agreement to comply with the open-access conditions set forth in $\S 157.103$ of the Subpart E Regulations; and a statement that any by-passed local distribution company and its state utility commission were served with the OEC application.

78. See, e.g., Alaska Natural Gas Transportation Act (ANGTA), 15 U.S.C. §719.

79. However, the OEC applicant must still file a statement of rates and pro forma tariff sheets and a statement explaining the derivation of rates. 
There has been a wide gap between $\mathrm{OEC}$ theory and practice. In the three and one half years since Order No. 436, only one relatively small OEC project has been certificated and built. Two others have been certified, but construction remains uncertain. Perhaps the key issue contributing to this poor record has been defining exactly how much risk of failure the sponsor has to assume. Recent developments, however, suggest that FERC is now prepared to act somewhat more responsively on OEC applications, albeit on a selective basis. In this regard the Department of Justice has been urging FERC to grant OEC certificates to all applicants in competitive contexts, leaving to the market the selection of the best project(s).

\section{Summary of OEC Applications}

Listed below are the principle pipeline projects filed to date under OEC procedures, with a brief summary of status and disposition, if any:

(a) Iroquois

A 330 mile line to move $350,000 \mathrm{Mcf} / \mathrm{d}$ of Canadian gas to the Northeast, was first filed as an OEC application in $1986 .^{80}$ After little progress at FERC for almost two years and facing stiff environmental opposition, Iroquois, in early 1988, filed a second, traditional section 7(c) application in the Northeast Open Season proceedings in $1988 .^{81}$ In consolidating many projects in the Northeast Open Season, FERC ruled that OEC applications would not be deemed competitive with standard section 7(c) projects proposing to serve the same market and thus would not be consolidated for comparative hearings. How and where they would be treated was left unclear. In the Open Season settlement process in late 1988, Iroquois only pursued its traditional section 7(c) application. By order issued May 2, 1989, FERC terminated a number of Open Season dockets, including Iroquois' OEC application. ${ }^{82}$

(b) Erie/Transylvania

This was another large scale project to transport Canadian gas to the Northeast, also filed as an OEC application in 1986 by ANR Pipeline and Transcontinental Gas Pipe Line Corp (Transco) ${ }^{83}$ In late-1986 FERC found the project not to qualify for the OEC procedure. ${ }^{84}$ Specifically, FERC found that ANR and Transco while proposing a modified fixed-variable rate design, with return on equity in the commodity charge and return of equity in the reservation fee - failed to assume sufficient risk. It also ruled that, for a project made up of several different pipeline segments operating jointly, all links (including corporate parents and affiliates) in the common chain must be open-access and filed under the OEC procedure, a requirement which Erie/Transylvania failed to meet. In addition, FERC held that it would still have to follow the full (and therefore time consuming) environmental review process for large projects with significant effect on the environment.

80. Iroquois Gas Transmission System, Docket No. CP86-523-000.

81. Docket No. CP88-198-000.

82. Northeast U.S. Pipeline Projects, Docket No. CP87-451,020, 47 FERC 961,172 (1989).

83. Erie Pipeline Company, Docket No. CP86-329-000.

84. "Order Suspending Proceeding and Directing Additional Filing", Great Lakes Gas Transmission Company, 37 FERC 961,270, Docket No. CP86-423-000 (December 22, 1986). 
After this order, Transco abandoned Transylvania. While ANR left Erie pending at FERC, later it, too, effectively abandoned it with a superseding section 7(c) application in the Northeast Open Season for a similar route, called the Eastco Project. ${ }^{85}$ In the same May 2, 1989, FERC order, supra, the Erie Project docket was terminated.

\section{(c) Moraine}

Only 17.8 miles of 20-inch pipe to connect its parent, Natural Gas Pipeline Company of America (NGPL), with Wisconsin Natural Gas, was filed under the OEC procedure in $1986{ }^{86}$ Wisconsin Natural's traditional pipeline supplier, ANR, protested and the FERC took no action for twenty months. On January 20, 1988, FERC issued an order summarily denying the OEC certificate, because Moraine's parent, NGPL, had not at that time accepted an open-access blanket certificate. ${ }^{87}$ NGPL's acceptance of its blanket certificate occurred soon thereafter, and, on February 2, 1988, FERC approved the Moraine OEC application, summarily rejecting ANR's competitive challenge. ${ }^{88}$

FERC imposed several restrictive certificate conditions on Moraine; nevertheless, NGPL accepted the OEC certificate and has built the 17 mile line. FERC doubled Moraine's proposed 10 year (based on service contract term) useful life for depreciation. It also required the same three year rate review imposed on non-OEC pipelines, although it subsequently dropped that condition upon rehearing. ${ }^{89}$ FERC further lowered Moraine's rate by raising the projected throughput from the proposed (market-calculated) $15 \mathrm{Bcf}$ to $54 \mathrm{Bcf}$, which is based solely on the maximum physical flow assuming NGPL's existing, peak day inlet pressure. Finally, it replaced Moraine's reservation fee (recovering most costs) with a volumetric rate, although expressing some sympathy for the need for a reservation fee in order to prevent customers from tying up firm capacity frivolously.

(d) WyCal

A 1,000 mile pipeline proposed by ANR from Wyoming to serve directly the EOR market in Southern California, was filed on August 4, 1987, as an OEC application. ${ }^{90}$ Potential competitors and previously-filed applicants for the EOR market, Kern River ${ }^{91}$ and Mojave ${ }^{92}$, asked FERC to dismiss the OEC application, while the California Public Utilities Commission (CPUC) asked that WyCal be consolidated with the other two..$^{93}$ On October 20, 1987, FERC denied these

85. Eastern American States Transmission Company, Docket No. CP88-193-000.

86. Moraine Pipeline Company, Docket No. CP86-492-000.

87. "Order Denying Certificates", Moraine Pipeline Company, 42 FERC 961,028 , Docket Nos. CP86-492-000 and CP86-494-000 (January 20, 1988).

88. "Order Vacating Prior Order, Issuing Optional Certificate and Blanket Certificate, and Denying Individual Certificate", Moraine Pipeline Company, 42 FERC 961,144, Docket Nos. CP86-492-000 and CP86-494-000 (February 2, 1988).

89. "Order Partially Granting Rehearing and Denying Rehearing and Convening Technical Conference", Moraine Pipeline Company, 43 FERC 961,118, Docket Nos. CP86-492-001, (April 26, 1988).

90. Wyoming-California Pipeline Company, Docket No. CP87-479-000.

91. Kern River Gas Transmission Company, Docket No. CP85-552-000.

92. Mojave Pipeline Company, Docket No. CP85-437-000.

93. Kem River and Mojave had each filed their certificate applications in the traditional, non-OEC manner and were proceeding through a competitive hearing process. 
requests. ${ }^{94}$ On March 23, 1988, however, FERC did consolidate WyCal for environmental review with these other projects, but not for comparative hearings. ${ }^{95}$ Then on July 1, 1988, FERC issued a declaratory order, in effect stating that, under conditions listed in the order and upon completion of the consolidated environmental review, it would issue WyCal an OEC certificate. ${ }^{96}$

In subsequent orders issued on November 14 and 30, 1988, FERC changed some of these conditions and issued WyCal the certificate, again conditioned on successful completion of environmental review.$^{97}$ By order issued on January 13, 1989, FERC gave its final environmental approval, which has the effect of making the WyCal OEC certificate operative.$^{98}$ However, without a sufficient customer base, WyCal is not yet ready for project financing, let alone construction. Finally, on March 15, 1989, FERC denied various requests for rehearing of WyCal's OEC certificate. 99

WyCal's OEC certificate reflects FERC's most current thinking on the OEC procedures and standards, in particular concerning reservation fees and assumption of risk. FERC accepted WyCal's reservation fee, based on the use of modified fixed-variable rate design, as reflecting sufficient risk assumption on the part of WyCal. The new WyCal risk assumption standard is that existing customers may not bear any risk of the new project, but new customers may voluntarily agree to share the risk as part of arms-length negotiations. FERC distinguished its earlier rejection of the same reservation fee for Erie/Transylvania, supra, as not involving voluntary arms-length negotiations. The reservation fee in the OEC certificate is a ceiling, up to which customers may negotiate; however, the sponsor must offer the lowest reservation fee negotiated to all prospective customers. Customers agreeing to a higher reservation fee receive a higher service priority and their commodity rate is lowered accordingly.

(e) Indiana-Ohio

Is an OEC project filed in the Northeast Open Season in January 1988 by Panhandle Eastern Pipe Line Corporation. ${ }^{100}$ It would run 200 miles, connecting Panhandle's system with eastern pipelines in Ohio, to move domestic supplies to unidentified Northeast markets. Indiana-Ohio was expressly excluded from the mass consolidation of applications in the Northeast Open Season because of its OEC nature. ${ }^{101}$ This has not, however, proved of benefit to Panhandle, because FERC has yet to act on the OEC application. At the same time, FERC has approved a settlement allowing an ANR proposal, containing almost the identical 24" pipe facility from Indiana to Ohio, to be processed as a separate project. ${ }^{102}$ Panhandle has protested this vigorously.

94. 41 FERC 961,040 (1987).

95. 42 FERC $961,351(1988)$.

96. 44 FERC $\{61,001$ (1988).

97. 45 FERC 961,234 (1988) and 45 FERC 961,353 (1988).

98. 46 FERC $\{61,029$ (1989).

99. 46 FERC $\$ 61,310$ (1989).

100. Indiana-Ohio Pipeline Company, Docket No. CP88-178-000.

101. "Order Consolidating Applications and Prescribing Procedures", Northeast U.S. Pipeline Projects, 42 FERC 961,332, Docket Nos. CP87-451-004, et. al. (March 17, 1988).

102. "Order Ruling on Discreteness of Additional Northeast Projects an Establishing Procedures", Northeast U.S. Pipeline Projects, 46 FERC 961,012, Docket No. CP87-451-016 (January 12, 1989). 


\section{(f) Mojave}

Responding to WyCal's success in obtaining expedited approval for its Wyoming to California line, they filed an OEC application as an alternative to its pending traditional section 7(c) application. ${ }^{103}$ The FERC in turn issued an OEC certificate to Mojave on May 8, $1989 .{ }^{104}$

\section{(g) Green Canyon}

A wholly-owned subsidiary of Transco Energy Company, Green Canyon was issued an OEC certificate on June 1, 1989, authorizing the construction and operation of approximately 66 miles of pipeline and related facilities in the outer continental shelf. ${ }^{105}$ These facilities will permit newly discovered gas reserves in the Green Canyon Block 184 Unit, offshore Louisiana, to be transported from production platforms to an interconnection with Transco's Southeast Louisiana Gathering system.

The OEC certificate granted by the FERC was conditioned in several respects. First, Green Canyon was to revise certain parameters for calculating the maximum initial rates including: (1) the use of a maximum capacity of $264,670 \mathrm{Mcf}$ per day as opposed to 219,671 Mcf per day as proposed by Green Canyon; (2) the use of a $14 \%$ rate of return of equity and hypothetical capital structure (70\% debt and 30\% common equity) rather than the proposed $15 \%$ equity allowance and Transco's capital structure; and (3) a 20-year depreciation life rather than Green Canyon's assumed 15-year life. ${ }^{106}$ Second, because Green Canyon proposed no differentiation of rates as to distance of haul or peak/offpeak usage, the Commission required Green Canyon to submit a section 4 rate filing at the end of the first three years of service. Finally, the authorized service was to commence within 20 months and the Commission required that Transco continue to operate under an open access blanket transportation certificate.

\section{Major OEC Issues}

While these OEC applications have raised a number of legal issues, two issues dominate: whether FERC's use of its OEC process meets the environmental standards of the National Environmental Policy Act (NEPA) ${ }^{107}$ and the due process requirements of the Ashbacker doctrine. ${ }^{108}$ These issues will likely arise more often in the case of a large-scale project filing as an OEC than for small supplier

103. Docket Nos. CP89-1-000 and CP89-2-000.

104. “Order Issuing Certificate”, Mojave Pipeline Company, 47 FERC 961,200 , Docket Nos. CP89-1-000, (May 8, 1989).

105. "Order Granting Certificate", Green Canyon Pipe Line Company, 47 FERC 961,310, Docket No. CP89-515-000 (June 1, 1989).

106. Based on these new rate parameters, the Commission derived a maximum rate of $8.11 \mathrm{c}$ per Dth as compared to the $10.3 \mathrm{C}$ Dth maximum rate developed by Green Canyon.

107. 42 U.S.C. $\$ 4332$ (2)(c). The NEPA issue is that FERC appears willing to issue one or more OEC certificates and not preclude issuing a traditional $\$ 7$ certificate, all to serve the same market; how does this approach fit with FERC's mandate under NEPA to consider alternatives and mitigate environmental impact by not approving more facilities construction than is needed to serve the market?

108. Ashbacker Radio Corp. v. FCC, 326 U.S. 327 (1945). The Ashbacker issue is the following: FERC is willing to grant an OEC certificate to WyCal before ruling on either the Kem River or Mojave projects; how does this approach fit with the Supreme Court's ruling that, where two or more applications for federal authorization are mutually exclusive (the grant of one will effectively preclude the grant of the others), the agency must decide between the competitors through a comparative hearing? 
laterals or market area by-pass lines. In the context of certifying WyCal, FERC has resolved that neither NEPA nor $A$ shbacker presents an insurmountable obstacle to the use of the OEC procedure. Ultimately, however, it is likely that the U.S. Courts of Appeal will be called upon to review FERC's thinking. ${ }^{109}$

\section{B. THE CALIFORNIA MARKET}

California has long been the principal export market for Canadian gas. Since the construction of the Pacific Gas Transmission Company (PGT) system in 1960, the Northern California market has been served via Pacific Gas and Electric Company (PG\&E) with substantial volumes of gas exported from Canada by PG\&E affiliate, Alberta and Southern (A\&S). Southern California began receiving some Canadian gas in 1981 as part of the ANGTS Western Leg Pre-Build. Following the CPUC's first round of transportation hearings in 1984 and 1985, the enhanced oil recovery (EOR) market was identified as a major incremental market, which led to direct interstate pipeline proposals being filed at FERC in 1985 by Kem River, Mojave and El Dorado ${ }^{110}$ (later dismissed for lack of prosecution). Interest in additional non-EOR markets (particularly Southern California utility markets) for Canadian gas has developed within the last year.

1. FERC Proceedings

(a) EOR Pipelines

The status of the three proposed interstate projects to serve the EOR requirements of California's primary heavy oil fields, in and around Kern County, has been discussed above in the context of WyCal's recent OEC certificate. It will also be addressed below in the context of developments within the state.

(b) PGT

In a traditional section 7(c) certificate application filed in late December 1988, PGT is proposing to loop its existing system from the Canadian border at Kingsgate, B.C. to Malin, Oregon, where PGT interconnects with PG\&E."' The project would involve completion of the ANGTS pre-build looping (42" O.D.) in the northern part of the system, between Kingsgate and the existing connection with Northwest Pipeline Company near Stanfield, Oregon, and an entire loop (36" O.D.) from Stanfield to Malin. By means of this expansion (and through the use of some displacement on the Northwest Pipeline system), PGT would be able to transport, on a firm basis, an incremental 600,000 MMMBtu's per day of Canadian gas directly to PG\&E and an incremental 150,000 MMBtu's per day to distribution companies in the Pacific Northwest.

PGT has entered into non-binding letters of intent with certain gas and electric utilities in Southern California regarding the use of a portion of the capacity to be made available by these facilities. The remaining capacity has been offered to other potential shippers through an auction program.

The pipeline expansion would be an all-firm transport line, and PGT has not proposed to make it an open-access pipeline. (PGT was not, when its expansion

109. On April 6, 1989, Mojave in fact petitioned for review of the FERC's WyCal certificate onders in the United States Court of Appeals for the D.C. Circuit. The matter is docketed as Case No. 89-1215.

110. El Dorado Interstate Transmission Company, Docket No. CP86-205-000.

111. Docket No. CP89-460-000. 
application was filed, an open-access transporter.) The pipeline is due to be ready for service by late 1993 . The estimated $100 \%$ load factor unit rate is about 60 cents/ MMBtu in current U.S. dollars. This rate would be designed to recover fully the costs of these new facilities. Rates for service on the existing PGT system (which is fully subscribed by PG\&E to move the A\&S system supply purchases at a very low rate due to three decades of depreciation) would be made largely without regard for these new facilities and services. However, compressor station retrofitting proposed in this application by PGT would probably improve the reliability of service on the original $36^{\prime \prime}$ system.

As noted, the markets targeted for service through the reserved portion of this expansion will all be utilities and will be located in Southern California (e.g., Southern California Edison, Long Beach, San Diego). From Malin, the gas would be moved south through California by means of system expansion facilities on the PG\&E system. This would be in the nature of an "Express Train" service: directly from Malin to Kern River Station, where PG\&E would dump the gas into SoCal Gas' system for delivery to the utilities in question. PG\&E filed its companion system expansion application with the CPUC on April 14, 1989.

PGT's application has been opposed at the FERC by a variety of interests. The EOR pipelines opposed it. A number of would-be shippers also opposed it, principally on grounds that it is anti-competitive. Some parties demanded that approval of PGT's system expansion be conditioned on PGT becoming open-access.

FERC has yet to establish hearing procedures of any kind. While the various restrictions proposed by PGT would most likely trigger detailed FERC scrutiny, it appears that, in the near term, activity on this proposal will take place in the CPUC context, as discussed below. In the final analysis, however, FERC will have to pass on the proposal.

(c) Altamont

Altamont is a project sponsored by several large Canadian producing companies, among them Mobil Canada, Shell Canada, Amoco Canada, Canadian Oxy, Petro-Canada, Alberta Energy Company and Home Oil. Nothing has yet been filed with FERC, but Altamont appears to comtemplate a large diameter, high pressure pipeline from the Canadian/U.S. border somewhere in Montana, running directly into Southern California. Deliveries would be made there directly to end users. The pipeline would be FERC-jurisdictional. In fact, one of the principle objectives of the project sponsors is to avoid any exposure to CPUC jurisdiction.

The Altamont sponsors have apparently completed a feasibility study, but, as noted above, no certificate application has yet been filed at FERC. It is unclear whether the project would be filed under the OEC procedures, or under traditional NGA section 7(c) procedures. There has also been some discussion whether the line should be scaled back, to end in Wyoming with downstream transportation to California via interconnection with a U.S. line, such as WyCal or Kern River.

(d) Southcoast

A different direct pipeline from Canada into Southern California was filed with FERC on October 1, 1988. ${ }^{12}$ The route would traverse Montana, Idaho, Utah, and Nevada and extend to Bakersfield, California. The 1,300 mile line was estimated to cost over $\$ 1$ billion and have capacity for $1.5 \mathrm{Bcf}$ per day. The application

112. Southcoast Transmission Corporation, Docket No. CP89-60. 
is very brief and there is no indication of financial backing. Other than noticing the application for intervention, FERC has taken no action.

\section{CPUC Proceedings}

California has historically taken the position that any pipelines located within the state should come within the jurisdiction of the CPUC. The two main California gas distribution companies, SoCal and PG\&E, have taken the same position. Thus, the three interstate pipelines serving the state (PGT, El Paso and Transwestern), all stop at the California border and SoCal and PG\&E operate from there, beyond FERC jurisdiction.

With the increased chances of one or more interstate pipelines into California actually being certified by FERC, the CPUC has initiated a proceeding to forge a "compromise" solution to the state's need for additional capacity. ${ }^{113}$ In the orders establishing this proceeding, the CPUC has admitted that some additional interstate pipeline capacity is appropriate, but has said that it will oppose any project which bypasses its jurisdiction altogether. The CPUC has tentatively determined that the PGT/PG\&E project passes this latter test, but that the Altamont project probably does not. It also said that Kern River is acceptable, based on a recent Kern River/SoCal Gas settlement, wherein (i) Kem River would interconnect with SoCal Gas as well as with EOR users and (ii) after a period of years (reportedly twenty), the entire Kern River system within Califormia would succumb to CPUC jurisdiction (by then, the heavy oil fields would presumably be largely depleted, so the affected EOR producers may not be opposed to this aspect of the deal).

Since issuance of these orders, another "deal" reportedly has been struck, this one involving WyCal and PG\&E. Under it, WyCal would interconnect with PG\&E, and PG\&E would be entitled to reserve capacity in WyCal, as well as an option to acquire equity in WyCal. This is expected to appeal to the CPUC in the same way as the Kern River/SoCal Gas arrangement has.

The CPUC directed project sponsors to apprise the CPUC of their efforts toward "global" settlement of the capacity question on or before April 25, 1989. Interested persons were also invited to submit comments by that date. If a satisfactory solution cannot be achieved privately by then, the CPUC has threatened to hold hearings, in which it will unilaterally determine - ignoring for the present FERC's concurrent if not exclusive authority - what is to be built, such determination to be forthcoming by August 3, 1989.

In the interim, PGT gave the prospective Southern California utility shippers until April 24, 1989 to complete precedent agreements. PGT also established an open season, which closed May 2, 1989, for Canadian suppliers to request firm capacity. Based on these ongoing events, PGT/PG\&E asked the CPUC to extend the April 25th deadline for settlement proposals. The CPUC agreed, extending the deadline until June 1, 1989. The details of capacity subscriptions on the PGT/PG\&E expansion are not yet public. Thus, at present the CPUC proceeding is on hold. 


\section{NORTHEAST U.S. MARKETS}

\section{Background}

The so-called "Northeast Open Season" proceeding before the FERC commenced in mid-1987 114 as a regulatory experiment to avoid the excessive regulatory delays experienced in the Boundary consolidated proceeding. ${ }^{115}$ FERC notified the public that any proposal to serve new markets in the Northeast (defined as New England, New York, New Jersey and Pennsylvania) had to be filed as complete certificate applications by a specific date, eventually extended to January $15,1988$.

In response, numerous applications were filed. The FERC on March 17, 1988, issued an order combining these and previously filed applications into 31 projects, with 20 being consolidated as potentially competitive projects, based on the standard of projects with common customers. ${ }^{116}$ Following various informal conferences to discuss environmental filings, market data and voluntary settlement, FERC on July 27, 1989, invoked the formal "Settlement Judge" procedure, giving the Chief Administrative Law Judge 90 days (later extended) of closed door meetings to thrash out settlement(s) of the competitive claims. ${ }^{117}$

While at the last possible minute the Settlement Judge was able to forge two settlements which eliminated the Ashbacker claims for comparative hearings, the result is not necessarily progress. Upon approving these settlements, FERC ordered the settlement projects' sponsors to file new or amended applications. Perhaps because the FERC Staff stayed clear of the settlement process, it is now handling these amended applications as if they were brand new. Thus, the last year was spent resolving but one issue, Ashbacker claims. While this is clearly an accomplishment, there are serious concerns about whether the settlement projects will be certified in the period of time demanded by the customers. In the meantime, the Canadian producing community generally appears to be tiring and reassessing its interest in the Northeast U.S. market.

\section{Niagara Projects}

With markets scheduled to commence primarily for 1989 and 1990 and the import point specified as Niagara, several projects settled competitive claims and negotiated joint ownership of two common facilities. First, Tennessee, National and PennEast (a partnership between units of Texas Eastern and CNG) agreed to jointly own and use a 30", 48-mile loop of Tennessee's Niagara Spur, called the Niagara Spur Loop Line, for the following projects: Transco/National System Expansion $(125,000 \mathrm{Mcf} / \mathrm{d}) ; \mathrm{TEMCO}(75,000 \mathrm{Mcf} / \mathrm{d}) ;$ PennEast Niagara Cogen (101,000 $\mathrm{Mcf} / \mathrm{d})$; National local deliveries (34,000 Mcf/d); and Tennessee cogen projects

114. "Notice Inviting Applications to Provide New Gas Service to the Northeast U.S.", Northeast U.S. Pipeline Projects, 40 FERC 961,087, Docket No. CP87-451-000 (July 24, 1987).

115. This proceeding involved proposed incremental imports of Canadian gas, initially at the Niagara import point, that were frustrated for over six years, in large part due to the uncontrolled administration of the comparative hearing requirements under the Ashbacker doctrine.

116. "Order Consolidating Applications and Prescribing Procedures", Northeast U.S. Pipeline Projects, 42 FERC 961,332, Docket Nos. CP87-451-004, et al. (March 17, 1988).

117. "Order Consolidating Projects and Ordering the Appointment of a Settlement Judge with Certain Directions", Northeast U.S. Pipeline Projects, 44 FERC 961,150, Docket No. CP87-451-006, (July 27, 1988). 
$(120,000 \mathrm{Mcf} / \mathrm{d})$. Second, National and PennEast agreed jointly to own and use the 24", 41-mile line from Ellisburg to Leidy, Pennsylvania, for their respective projects.

The Chief Judge certified the Niagara Settlement to FERC on November 18, 1988. ${ }^{118}$ Over Champlain Pipeline's sole objection, FERC approved the Niagara Settlement on January 12, 1989. ${ }^{119}$ The resulting new and amended applications were then filed, publicly noticed by FERC and intervened in by various entities. At present some of the applications are being processed. ${ }^{120}$ But as explained below, the certificate application filed by Great Lakes in support of TransCanada has put most FERC review on hold, because of the dependence of these Niagara projects on the Great Lakes capacity.

\section{Iroquois and Champlain Projects}

The most contentious Ashbacker dispute involved the Iroquois Project and several competing projects, principal among which was Champlain Pipeline. ${ }^{121}$ Iroquois is a U.S. partnership, comprised of more than a dozen U.S. and Canadianbased companies. The history of its pipeline project is discussed in the "Optional Expedited Certificate" segment of this paper. Champlain is also a consortium of U.S. and Canadian entities, having as its objective the construction and operation of a pipeline from the eastern U.S./Canadian border to Northeast U.S. markets. To a significant extent, either pipeline could be sized and shaped to serve markets targeted by the other.

During the Settlement Judge process, there were unsuccessful attempts to meld all competing interests into a single amalgam facility, with joint ownership by the various warring companies. What finally transpired out of the settlement process was an agreement of the contestants to allow the customers to sign exclusive commitments to just one project and then to honour those choices by proposing facilities to serve those customers that did subscribe. Service was slated to be phased in for 1991 and 1992.

What resulted from that process are three separate projects: (1) revised Iroquois; (2) revised Champlain, for Canadian gas; and (3) revised Eastco, now ANR/ Columbia, for domestic U.S. gas. FERC approved this settlement on January 12 , $1989^{122}$ and various new applications have been filed. While some initial environmental review has occurred, such as local scoping hearings, FERC has notified Iroquois and Champlain that the absence of upstream TransCanada (and Great Lakes) regulatory filings will cause suspension of that review.

The fundamental problem with the Iroquois/Champlain settlement concept is that the efficiencies of a single, larger project have been lost. The resulting higher transportation costs in the U.S., when combined with the rumoured level of

118. "Certification of Niagara Import Projects as Discrete", National Fuel Gas Supply Corporation, 45 FERC 963,015, Docket No. CP88-194-000, et. al.(November 18, 1988).

119. "Order Finding Niagara Import Point Projects Discrete", Northeast U.S. Pipeline Projects, 46 FERC 961,013, Docket No. CP87-451-017, (January 12, 1989).

120. On July 27,1989 , the Commission issued an order granting certificate authorization for the construction and operation of facilities necessary for the implementation of storage service for the Transco System Expansion Project. See, "Order Issuing Certificates and Approving Abandonment", National Fuel Gas Supply Corporation, Docket Nos. CP88-194-000, 48 FERC 961,121 (July 27, 1989).

121. Champlain Pipeline Company, Docket No. CP88-168-000.

122. 46 FERC 961,012 (1989). 
upstream facilities construction and resulting cost in Canada, make the prospect of acceptable netbacks to Alberta problematic. Moreover, with the spillover to netbacks for existing sales to Eastern Canada, the Canadian Petroleum Association (CPA) has submitted evidence before the NEB proposing the so-called " 1.2 test" for cost allocation/rate design on the TCPL system. Irrespective of how the NEB ultimately treats the CPA proposal in the 1990 facilities docket, the storm clouds are massing for the upcoming 1991 application. To date, Champlain's inability to contract for long-term supplies for its shippers is a manifestation of this problem.

\section{Great Lakes Expansion For TransCanada Capacity}

In Docket No. CP89-892-000, Great Lakes Gas Transmission Company (Great Lakes) filed an application requesting authorization to provide additional firm gas transportation of 417,500 Mcf per day for TransCanada in conjunction with its 1990 facilities filing before the NEB. This firm transportation would be from a point of interconnection between the facilities of Great Lakes and TransCanada on the International Boundary at Emerson, Manitoba to export points on the International Boundary located at Sault Ste. Marie and St. Clair, Michigan. A substantial portion of the proposed service would be utilized for the Niagara Settlement projects previously described.

Great Lakes proposes to construct seventeen loop sections, totalling 459.6 miles, of 36-inch diameter pipe and twenty-five aerodynamic assemblies at various Great Lakes' compressor stations, at a cost of $\$ 438,498,900$. While Great Lakes proposes to charge its existing T-4 tariff rate to TransCanada, the application shows a $\$ 70$ million resulting revenue deficiency, which means that the new facilities are far more expensive than the existing ones. Not surprisingly, two of Great Lakes U.S. customers, Michigan Consolidated Gas Company and Natural Gas Pipeline Company of America, have protested the application because of the likely rate increase that would follow.

The Great Lakes filing poses three major difficulties for the Niagara Settlement projects:

(1) The magnitude of the proposed facilities has caught the FERC Staff by surprise. Because a full environmental impact statement appears necessary, processing the Great Lakes application could well delay the processing of the Niagara Projects, which, with the much more limited scope of facilities proposed, appeared likely to require less extensive environmental review. It is too early to say whether the 1990 target in-service date will be missed as a result. (2) The substantial increase in the unit cost on Great Lakes could, despite well-established precedent, threaten the availability to TransCanada of rolled-in rates on the Great Lakes system. Should this occur, one must wonder what impact would it have before the NEB, and on project economics generally.

(3) Great Lakes remains a non-open access transporter. In addition, there have been complaints that Great Lakes has discriminated in its transportation services. This fact has not been lost on FERC, which in a recent order "note [d] that Great Lakes Gas Transmission Company, which is a closed pipeline, also has an application on file in Docket No. CP89-892-000 related to the Niagara Import Point Projects." 123 Veterans of the open-access evolutionary process in the U.S. will recognize this as the proverbial "writing on the wall" for Great Lakes: in order to win FERC approval for its intended system expansion, Great Lakes will, in all likelihood, have to apply for and accept a blanket certificate to perform third party transportation services in compliance with the standards set forth in Part 284 of the regulations (18 C.F.R. Part 284).

123. "Order Amending Certificates", National Fuel Gas Supply Corporation, 47 FERC $\$ 61$, 122, Docket Nos. CP88-225-002 (April 27, 1989). 


\section{CONCLUSION}

Even as these final words are written, the members of the FERC are debating in open session the merits of the rate reform initiative mentioned in Section II of this paper. ${ }^{124}$ Change and uncertainty are clearly going to remain with us awhile longer.

This evolutionary process, however, appears gradually to be making its way toward a natural culmination, in which the contract, rather than the regulatory process, will be the principal determinant of right and obligation as between industry participants at the interstate level. Where sponsors are willing to assume the risk, projects will be given construction approval, subject only to the requirement that they meet applicable environmental protection standards. Where questions of anticompetitive behavior regarding the use of interstate facilities arise, the FERC will assume the role of referee. State utility commissions (a force not treated in detail in this paper) will be called upon to shoulder responsibilities historically bome by the federal government (e.g., assessing the prudence of distributor gas purchasing practices) and, because of the highly political nature of utility regulation in many states, predictability will likely be difficult.

As legal specialists upon whom the industry will depend for guidance, we can view this either as a nightmare or as an opportunity to contribute toward influencing the regulatory process and toward understanding and applying it to serve the interests of the client. I must assume that, like myself, the members of the Foundation generally prefer the latter view and look forward to the challenge.

124. The overwhelming majority of this paper was written prior to the Jasper conference, held in June 1989. Certain portions have been updated to address significant actions occurring between then and the end of August, 1989. Because of the breadth of this paper, however, unless otherwise specifically noted, the reader should assume that this paper was current as of May 1989. 